UNIVERSIDADE DE SÃO PAULO

FACULDADE DE MEDICINA DE RIBEIRÃO PRETO

DEPARTAMENTO DE GENÉTICA

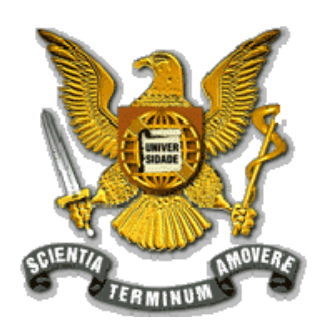

Daniel Antunes Moreno

\title{
ESTUDO DA EXPRESSÃO DOS GENES DE CLASSE I DAS HISTONAS DESACETILASES (HDACs 1, 2, 3 e 8) EM LEUCEMIA LINFÓIDE AGUDA DE CRIANÇAS E ADOLESCENTES
}

Dissertação apresentada à Faculdade de Medicina de Ribeirão Preto da Universidade de São Paulo para a obtenção do título de mestre em ciências, área de concentração Genética. 


\title{
FOLHA DE APROVAÇÃO
}

\author{
Daniel Antunes Moreno
}

Estudo da expressão dos genes de classe I das histonas desacetilases (HDACs 1, 2, 3 e 8) em leucemia linfóide aguda de crianças e adolescentes.

Dissertação apresentada à Faculdade de Medicina de Ribeirão Preto da Universidade de São Paulo para a obtenção do título de mestre em ciências, área de concentração Genética.

Aprovado em:

Banca Examinadora

Prof. Dr.

Instituição:

Assinatura:

Prof. Dr.

Instituição:

Assinatura:

Prof. Dr.

Instituição: Assinatura: 


\section{Dedico Este Trabalho Especialmente}

Aos meus pais Roberto e Matilde, ao meu irmão Douglas, às minhas

irmãs Adriana e Sílvia, a Janaína, a minha família e a todos os meus amigos. 


\section{Agradecimentos}

Agradeço ao meu orientador Professor Dr. Luiz Gonzaga Tone pela sabedoria, pela paciência e pela confiança.

Ao Professor Dr. Carlos Alberto Scrideli pela colaboração e pelas sugestões importantes neste trabalho.

À Professora Dra. Andréa Cecchi pela confiança e amizade.

À Dra. Rosane de Paula Gomes Queiroz pela colaboração durante a realização deste trabalho.

À Dra. Maria Sol Brassesco Annichini pela amizade, pelos conselhos e pela ajuda na realização deste trabalho.

À Msc. Maria Angélica Abdalla de Freitas Cortez Tavares pelos conselhos, pela amizade e pelo apoio.

Ao Professor Fábio Mota e à Professora Dra. Renata Canalle pelo companheirismo, pelos conselhos e por todo apoio. 
Ao Dr. Fábio Morato pela amizade, pelos conselhos e pelo apoio durante a realização deste trabalho.

\begin{abstract}
À Msc. Vanessa Silveira pelo apoio pela amizade e pela ajuda durante o curso de mestrado.
\end{abstract}

Ao Professor Angel Maurício e à sua esposa Angela pela amizade, pelo companheirismo e pelo apoio.

Ao Biomédico Kleiton Borges pela amizade, pelos conselhos e por todo apoio durante a realização deste trabalho.

Ao Msc. Elvis Cueva e à bióloga Sabrina pela amizade, pelas sugestões e pelo apoio.

À biomédica Priscila Leite pela colaboração.

À Dra. Agda Karina Brodoloni Eterovic pelas sugestões e pelo apoio neste trabalho.

Aos membros da equipe de funcionários do laboratório de citogenética Sônia e Aidê pela amizade e pela boa convivência. 
Ao Professor Dr. Elvis Valera e Dra. Fabiana Valera.

À secretária do departamento Helena pela ajuda concedida durante sua permanência no Hospital das Clínicas.

Às funcionárias do Departamento de Genética Susie e Aparecida Helena pela paciência, pela disposição em ajudar sempre e por todo apoio durante o curso.

Ao Conselho Nacional de Pesquisa (CNPq) pela concessão da bolsa de mestrado.

À Fundação de Apoio ao Ensino, Pesquisa e Assistência do Hospital das Clínicas da Faculdade de Medicina de Ribeirão Preto da Universidade de São Paulo (FAEPA) pelo auxílio financeiro.

Ao Hospital das Clínicas da Faculdade de Medicina de Ribeirão Preto e à Universidade de São Paulo (HC/FMRP-USP). 
“O equilíbrio é o princípio das decisões corretas, a determinação é o segredo para vencer obstáculos e o sucesso é conseqüência de um sonho na presença de equilíbrio e determinação" 


\section{RESUMO}

\section{ESTUDO DA EXPRESSÃO DOS GENES DE CLASSE I DAS HISTONAS DESACETILASES (HDACS 1, 2, 3 E 8) EM LEUCEMIA LINFÓIDE AGUDA DE CRIANÇAS E ADOLESCENTES.}

A Leucemia Linfóide Aguda (LLA) é uma doença heterogênea em relação à biologia e ao prognóstico. Além de alterações genéticas, anormalidades epigenéticas, estão estreitamente relacionadas ao processo de carcinogênese e entre os mecanismos epigenéticos, a acetilação das histonas é um componente essencial para a regulação da estrutura da cromatina e atividade transcricional. Esse processo é mediado pelas histonas acetiltransferases (HATs). Por outro lado, a desacetilação, por meio das histonas desacetilases (HDACs), está relacionada à condensação da cromatina e repressão transcricional. A expressão anormal das HDACs tem sido associada ao processo de leucemogênese, revelando ser uma área promissora na caracterização de grupos de risco e tratamento do câncer. Os objetivos deste trabalho foram avaliar a expressão dos genes da classe I de HDACs (HDAC 1, 2, 3 e 8), correlacionar os resultados com as características clínicas e de prognóstico (idade, gênero, grupo de risco, contagem inicial de blastos, imunofenótipo, resposta ao tratamento, doença residual mínima nos dias 14 e 18 e a sobrevida livre de eventos) em 46 amostras consecutivas de medula óssea de crianças e adolescentes portadores de LLA; comparar e correlacionar a expressão dos genes estudados entre as amostras de pacientes portadores LLA e 10 amostras de medula óssea sem doença hematológica. A análise da expressão gênica foi realizada através da técnica de PCR em Tempo Real pelo método TaqMan ${ }^{\circledR}$. Foi observado um aumento da expressão do gene $H D A C l$ nas amostras dos pacientes bons respondedores ao 
tratamento. $\mathrm{O}$ gene $H D A C 2$ foi mais expresso no grupo de pacientes do gênero masculino $(p=0,038)$. Esse gene também mostrou uma expressão aumentada nos pacientes de alto risco $(p=0,060)$ e com sobrevida menor $(p=0,065)$, entretanto os valores encontrados não foram estatisticamente significativos. Além disso, foi observada uma expressão aumentada dos genes HDAC2 $(\mathrm{p}=0,007), H D A C 3$ $(\mathrm{p}=0,014)$ e HDAC8 $(\mathrm{p}=0,002)$ em amostras de pacientes com LLA quando comparadas às amostras de medula óssea sem doença hematológica. Houve correlação entre a expressão de todos os genes de classe I das HDACs, exceto entre $H D A C 1$ e $H D A C 8$. Os resultados obtidos nesse trabalho sugerem que as HDACs de classe I, podem representar importantes alvos para futuros estudos em LLA, no entanto são necessários de testes funcionais para confirmar estes resultados.

Palavras Chave: Leucemia linfóide aguda, histonas desacetilases, acetilação, criança. 


\section{ABSTRACT}

\section{CLASS 1 HISTONE DEACETYLASES GENE EXPRESSION IN CHILDHOOD ACUTE LYMPHOBLASTIC LEUKEMIA}

Acute Lymphoblastic Leukemia (ALL) is a heterogeneous disease with distinct biologic and prognostic groups. In addition to genetic alterations, epigenetic processes play an important role in carcinogenesis, among which histone acetylation/deacetylation is crucial for chromatin modulation structure and transcriptional activity. Histone acetylation is regulated by the enzyme histone acetyl transferases (HATs). On the other hand, the deacetylation process is regulated by histone deacetylases (HDACs) enzymes, which is associated with the chromatin condensation and transcriptional repression. Abnormal expression of HDACs is a common feature of cancer and has revealed a promising field to stratify cancer treatment and risk classification. The investigation of these expression profiles may represent an important clinical factor for diagnosis and management of hematological malignances. The objectives of the present study were to analyze the expression profile of the class 1 HDACs ( $H D A C 1,2,3$ and 8$)$ genes in bone marrow samples obtained from 46 childhood ALL samples, to correlate the results with prognostic and clinical features (age, gender, risk group, immunophenotype, treatment response, minimal residual disease and event free survival) of the patients; to evaluated differences in gene expression between ALL samples and 10 bone marrow samples without hematological disease and to verify the correlation of these genes. The gene expression analysis were made using 
TaqMan real-time polymerase chain reaction. A higher expression of $H D A C 1$ in patients with better treatment response was observed. The $H D A C 2$ showed a higher expression in male gender $(\mathrm{p}=0,038)$. HDAC2 also showed a higher expression for higher risk $(p=0,060)$ and lower survival patients $(p=0,065)$, however the statistical analysis did not show significant results. Furthermore, there was a higher expression of HDAC2 $(\mathrm{p}=0,007), H D A C 3(\mathrm{p}=0,014)$ and HDAC8 $(\mathrm{p}=0,002)$ in ALL samples when compared to healthy donors. Class I HDACs showed correlation in gene expression, except for $H D A C l$ and $H D A C 8$. These results suggest that class I HDACs can represent important targets for ALL research; however, it is necessary to perform functional investigation to confirm these results.

Key words: Acute lymphoblastic leukemia, histones deacetylases, acetylation, childhood. 


\section{INDICE DE FIGURAS}

Figura 1. Comparação da expressão dos genes de classe I das HDACs em 46 amostras de pacientes com LLA e 10 de amostras medula óssea de doadores sem doença hematológica.

Figura 2. Curvas de Kaplan-Meier e resultado do teste de Log-Rank obtido através da análise da expressão relativa do gene $H D A C 1$ e sobrevida livre de eventos dos pacientes portadores LLA.

Figura 3: Curvas de Kaplan-Meier e resultado do teste de Log-Rank obtido através da análise da expressão relativa do gene $H D A C 2$ e sobrevida livre de eventos dos pacientes portadores LLA.

Figura 4: Curvas de Kaplan-Meier e resultado do teste de Log-Rank obtido através da análise da expressão relativa do gene $H D A C 3$ e sobrevida livre de eventos dos pacientes portadores LLA. 
Figura 5: Curvas de Kaplan-Meier e resultado do teste de Log-Rank obtido através da análise da expressão relativa do gene $H D A C 8$ e sobrevida livre de eventos dos pacientes portadores LLA.

Figura 6. Teste de Spearman: correlação linear entre os genes estudados. 


\section{INDICE DE TABELAS}

Tabela 1 - Esquema de classificação de risco da World Health Organization (WHO) em pacientes com LLA.

Tabela 2 - Classificação das Histonas Desacetilases.

Tabela 3 - Características do diagnóstico e situação clínica atual dos pacientes com LLA avaliados e admitidos no Hospital das Clínicas da Faculdade de Medicina de Ribeirão Preto da Universidade de São Paulo (HC/FMRP-USP) no período de janeiro de 1998 a janeiro de 2006.

Tabela 4 - Seqüência dos primers para a PCR em tempo real dos genes GUS $\beta$, HDAC1, HDAC2, HDAC3 e HDAC8.

Tabela 5 - Valores da expressão relativa dos genes de classe I das HDACs em amostras de medula óssea de pacientes portadores de LLA. 
Tabela 6 - Valores de "p" obtidos através do teste de Fisher relativos à expressão dos genes de Classe I das HDACs nas amostras de medula óssea dos pacientes portadores de LLA.

Tabela 7 - Valores de "p" obtidos através do teste de Mann-Whitney relativos à expressão dos genes de classe I das HDACs nas amostras de medula óssea dos pacientes portadores de LLA.

Tabela 8 - Genes envolvidos no desenvolvimento e progressão do câncer cuja expressão é alterada na presença de iHDAC. 


\section{SIGLAS E ABREVIATURAS}

A Adenina

ABL Abelson Murine Leukemia

ADP Adenosina difosfato

AML1 Acute Myeloid Leukemia 1

Ar Arginina

ATP Adenosina trifosfato

BCR Breakpoint Cluster Region

C Citosina

CALLA Common ALL Antigen

CD Cluster de diferenciação

cDNA DNA complementar

Ct Cycle Threshold

DEPC Dietilpirocarbonato

DMSO Dimetilsulfito

DNA Ácido Desoxirribonucléico

DNMT DNA Metiltransferase

dNTP Desoxiribonucleotídeos Trifosfatos 


$\begin{array}{ll}\text { dUTP } & \text { Desoxiuridina Trifosfato } \\ \text { DRM } & \text { Doença Residual Mínima } \\ \text { EDTA } & \text { Ácido Etilenodiaminatetracético } \\ \text { FAB } & \text { Classificação Francesa-Americana-Britânica } \\ \text { G } & \text { Guanina } \\ \text { GB } & \text { Glóbulos brancos } \\ \text { LLA } & \text { Leucemia Linfoblástica Aguda } \\ \text { LMA } & \text { Leucemia mieloblástica aguda } \\ \text { Lis } & \text { Lisina }\end{array}$

N-terminal Amino-terminal

HDAC Histonas Desacetilases

HAT Histonas Acetiltransferases

RT-PCR Reação em cadeia da polimerase da transcrição reversa

PBS Tampão fosfato-salina

PCR Reação em cadeia da polimerase

RNA Ácido Ribonucléico

rpm Rotações por minuto

SLE Sobrevida Livre de Eventos

SNC Sistema Nervoso Central

Ser Serina 
Timina

TEL Translocation Ets Leukemia

TCR Receptor de Células T 


\section{SUMÁRIO}

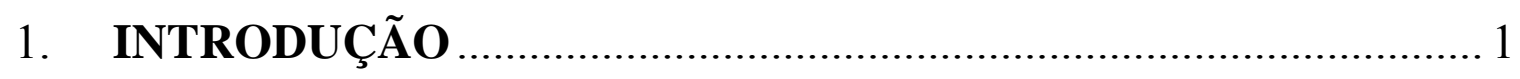

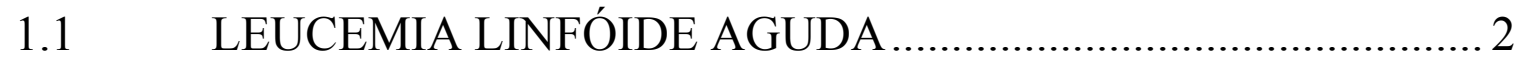

1.1.1 Histórico e Classificação das Leucemias........................................... 2

1.1.2 Características Gerais da Leucemia Linfóide Aguda ....................... 6

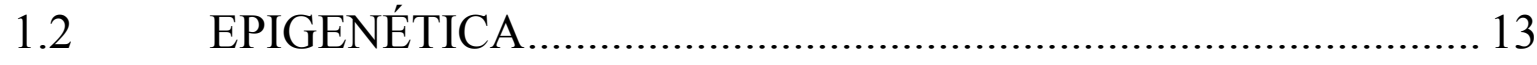

1.2.1 Epigenética: Conceitos Gerais ........................................................ 13

1.2.2 Epigenética e Câncer...................................................................... 16

1.3 HISTONAS DESACETILASES ……………………………...... 19

1.3.1 Cromatina e a Acetilação das Histonas...………………………..... 19

1.3.2 Classificação das HATs e HDACs ................................................. 23

1.3.3 Histonas Desacetilases e Câncer....................................................... 27

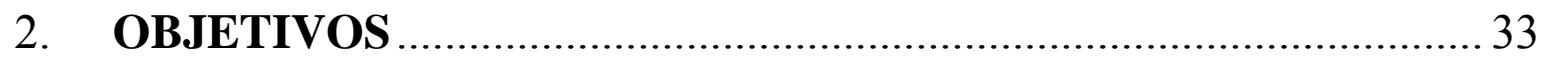

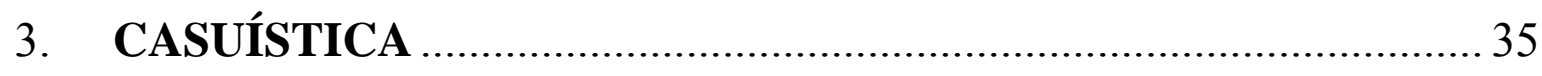

4. MATERIAL E MÉTODOS.............................................................. 42

4.1 Coleta e processamento das Amostras de Medula Óssea ................. 43

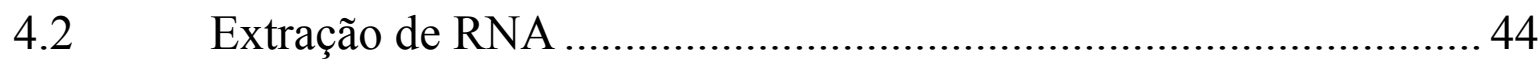

4.3 Síntese do DNA complementar (cDNA) ………………................. 45 


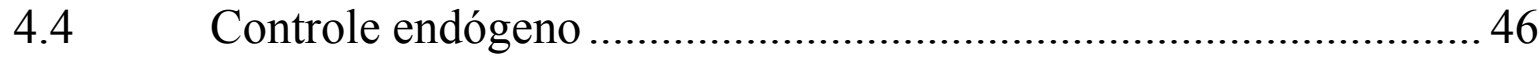

4.5 Oligonucleotídeos ….............................................................. 47

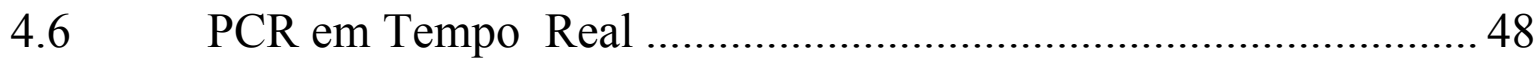

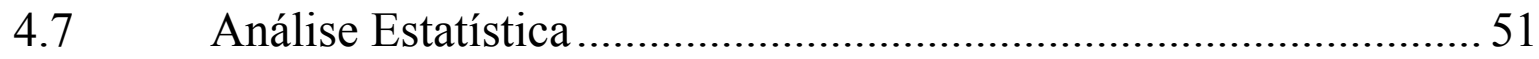

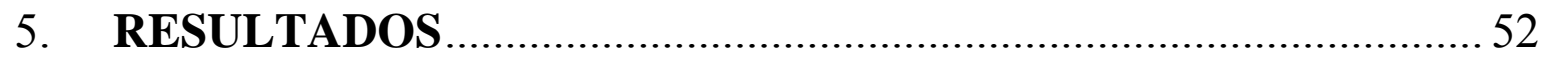

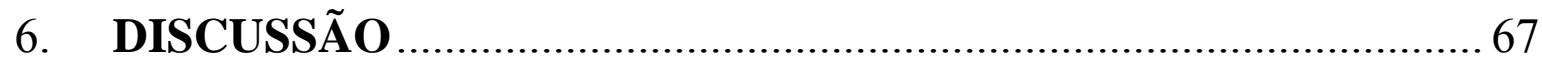

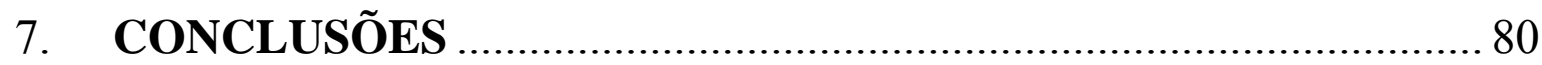

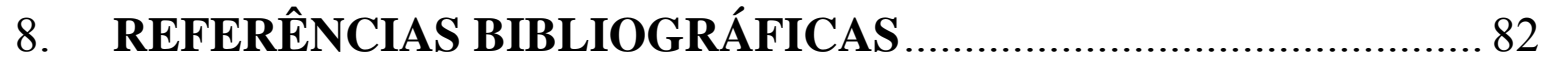

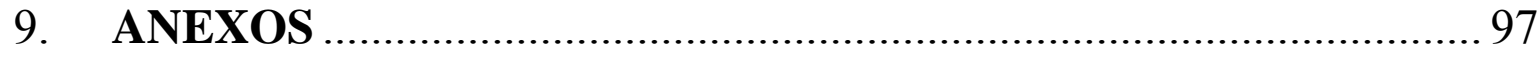

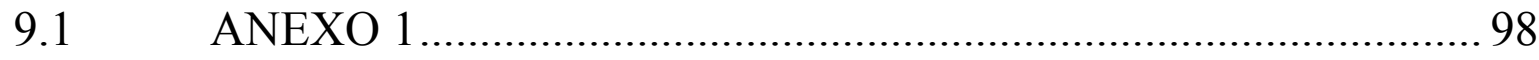

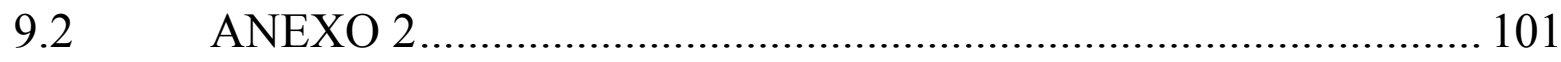

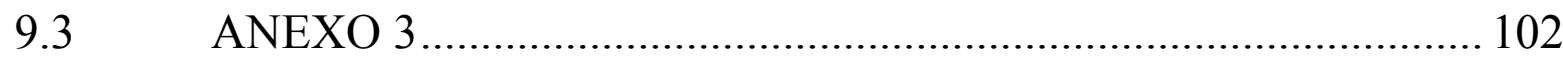




\section{INTRODUÇÃO}




\subsection{LEUCEMIA LINFÓIDE AGUDA}

\subsubsection{Histórico e Classificação das Leucemias}

As leucemias são neoplasias que se originam a partir de células transformadas na medula óssea, e assim como em outros tipos de câncer, essa transformação resulta de múltiplos eventos de seleção que envolve alterações genéticas, epigenéticas e ambientais (IRONS; STILMANN, 1996).

O primeiro caso de leucemia foi descrito em 1827 por Velpeau. Seu paciente apresentava aumento do abdômen, febre, fraqueza e sintomas de litíase renal. Ao primeiro diagnóstico Velpeau havia constatado um aumento do fígado e baço e o sangue apresentava uma consistência viscosa. $\mathrm{O}$ paciente faleceu em pouco tempo, assim que foi admitido ao hospital (BEUTLER, 2001; GUNZ, 1990).

Apesar das observações de Velpeau, a leucemia só foi caracterizada como uma doença distinta em 1845, coincidentemente por dois cientistas em relatos de casos diferentes. Um desses cientistas, o patologista britânico John Bennett, atribuiu de maneira imprópria o termo leucocitopenia. O outro foi o patologista alemão Rudolf Virchow que dois anos mais tarde introduziu o termo leucemia para descrever a doença (BEUTLER, 2001; GOLDMAN, 2003; GUNZ, 
1990). Continuando suas investigações, em 1856, Virchow classificou a leucemia em dois subtipos: esplênica (ou associada a esplenomegalia) e linfática (associada a grande linfoadenopatia). No ano seguinte, a leucemia aguda foi descrita por Friedreich e em 1878, Neumann descreveu a leucemia de origem mielóide (PUI, 1999a).

A introdução dos métodos de coloração de células em 1891 por Ehrlich permitiu a diferenciação dos leucócitos e das células leucêmicas e a leucemia esplênica e mielogênica foram definidas como uma mesma doença originada de um precursor mielóide. Também se tornava aparente que as leucemias agudas caracterizavam se pela presença de leucócitos anormais no sangue, e não por uma leucocitose. A partir do início do século $\mathrm{XX}$ as leucemias passaram a ser classificadas nas formas agudas e crônicas e o progresso na descrição da leucemia continuou paralelamente ao desenvolvimento de novas tecnologias como microscopia eletrônica, análise cromossômica, imunofenotipagem e biologia molecular (PUI, 1999a).

Atualmente as leucemias são classificadas em agudas ou crônicas, de acordo com o grau de maturação das células neoplásicas e em mielóides ou linfóides de acordo com a origem celular. As leucemias agudas são caracterizadas pela proliferação excessiva de células imaturas na medula óssea, enquanto as leucemias crônicas caracterizam-se pela proliferação de células maduras e 
diferenciadas. Assim, as leucemias são classificadas em: Leucemia Linfóide Aguda (LLA), Leucemia Linfóide Crônica (LLC), Leucemia Mielóide Aguda (LMA) e Leucemia Mielóide Crônica (LMC) (PUI, 1999a).

De modo geral, a leucemia é a neoplasia mais comum na infância e representa aproximadamente $30 \%$ dos casos de câncer pediátricos (BELSON; KINGSLEY; HOLMES, 2007). Entre os diversos tipos de leucemia a LLA é a mais comum em crianças e adolescentes (PUI; EVANS, 2006). Além disso, representa uma doença heterogênea em relação à biologia e ao prognóstico (KEBRIAEI, 2003).

Com base na expressão de antígenos, a LLA pode ser classificada em diferentes estágios de maturação das células B e T (pré-B precoce ou pró-B, pré-B, pré-B transicional, B madura, pré-T e célulasT maduras) (PUI; JEHA, 2007). As LLAs provenientes de precursores de células B apresentam um antígeno em comum, o CD10 e passaram a serem identificadas como Leucemia CALLA + (Common ALL Antigen), CD10 + ou Leucemia comum. (MARGOLIN; STEUBER; POPLACK, 2002). A LLA-B (CALLA+) está geralmente associada a um prognóstico melhor em relação à LLA-T (BENE; FAURE, 1997; FARIAS; CASTRO, 2004). Aproximadamente $85 \%$ dos casos de LLA infantil expressam marcadores originados do precursor B e 15\% expressam marcadores da linhagem $\mathrm{T}$ (KEBRIAEI, 2003). 
A incidência da LLA provenientes de células $T$ em crianças do gênero masculino é ligeiramente maior em relação ao gênero feminino (BELSON; KINGSLEY; HOLMES, 2007; RIES et al., 1998). O gênero é considerado um fator importante no prognóstico da LLA infantil, entretanto o pior prognóstico em pacientes do gênero masculino pode ser explicado em parte pela maior incidência de LLA-T e pela infiltração testicular. Além disso, sabe se que alguns agentes antileucêmicos parecem apresentar melhores resultados em pacientes do gênero feminino (BELSON; KINGSLEY; HOLMES, 2007; PUI, 1999b).

As características morfológicas dos blastos são muito variáveis e de acordo com o esquema de classificação do grupo Francês-Americano-Britânico (FAB) os blastos na LLA são divididos nos subtipos L1, L2 e L3 (KEBRIAEI, 2003). O subtipo L1 é caracterizado pela presença de linfoblastos pequenos com núcleo regular, citoplasma escasso e são particularmente comuns em casos pediátricos. O subtipo L2 apresenta células maiores e heterogêneas, núcleo com formato irregular e quantidade de citoplasma moderadamente abundante. O subtipo L3 caracteriza-se pela presença de células grandes e homogêneas com núcleo grande com formato regular redondo ou oval e citoplasma moderadamente abundante normalmente contendo vacúolos (FARIAS; CARTRO, 2004; KEBRIAEI, 2003). A morfologia L1 está associada a maiores índices de remissão e sobrevida quando comparada à morfologia L2, entretanto ainda não foi identificada 
nenhuma base biológica que explique essas diferenças morfológicas (MARGOLIN; STEUBER; POPLACK, 2002). O subtipo L3 é conhecido como Leucemia de células-B maduras apresentando propriedades claramente distintas dos demais subtipos (KEBRIAEI, 2003).

\subsubsection{Características Gerais da Leucemia Linfóide Aguda}

A LLA é uma neoplasia hematológica caracterizada pela proliferação de células precursoras da linhagem linfóide na medula óssea (HARRISON, 2001; KEBRIAEI, 2003). A proliferação e acúmulo desses linfoblastos na medula óssea resultam na supressão da hematopoiese normal e pode acometer vários órgãos, principalmente o fígado, baço, linfonodos, timo, meninges e as gônadas (PUI; JEHA, 2007). Os sintomas da LLA resultam de vários graus de anemia, neutropenia, trombocitopenia e da infiltração dos linfoblastos em outros tecidos (REICHMANN, 2000).

Embora possa ocorrer em qualquer faixa etária, a LLA é a neoplasia mais comum na infância (GAYNON, 2006; HARRISON, 2001; KEBRIAEI, 2003; PUI; JEHA, 2007; REICHMANN, 2000) sendo que o pico de incidência está entre 2 e 5 anos (BELSON; KINGSLEY; HOLMES, 2007; HARRISON, 2001; KEBRIAEI, 
2003). Em contraste, a ocorrência deste tipo de leucemia é pouco freqüente em adultos e parece haver um aumento da incidência em indivíduos com mais de 50 anos (KEBRIAEI, 2003; HARRISON, 2001). As características clínicas e biológicas da doença são diferentes entre crianças, adultos e pacientes com idade mais avançada (LARSON, 2005). Além disso, há um pior prognóstico com o aumento da idade (PUI; EVANS, 2006).

A cada ano, cerca de 2.500 crianças e adolescentes com LLA são diagnosticadas nos Estados Unidos (PUI; EVANS, 2006). Nas últimas décadas houve um aumento no número de casos de LLA que embora não seja estatisticamente significativo, deve-se provavelmente aos avanços nas técnicas do diagnóstico e detecção da doença (BELSON; KINGSLEY; HOLMES, 2007). Apesar dos avanços obtidos nas técnicas de diagnóstico e tratamento, ainda não estão bem claros os aspectos etiológicos da LLA, entretanto acredita-se que a transformação leucêmica resulta de múltiplos processos que podem envolver interações complexas entre diversos fatores genéticos, hereditários, imunológicos, epigenéticos e ambientais (IRONS; STILMANN, 1996; KEBRIAEI, 2003). O benzeno e a radiação ionizante estão entre os fatores ambientais mais comumente associados ao desenvolvimento da leucemia infantil (BELSON; KINGSLEY; HOLMES, 2007; INFANTE-RIVARD; GUIGUET, 2004). 
De modo geral, os mecanismos genéticos envolvidos na transformação leucêmica incluem a expressão aberrante de proto-oncogenes, aneuploidias e translocações cromossômicas que geram genes de fusão que codificam fatores de transcrição modificados. Essas anormalidades resultam em uma capacidade anormal de proliferação, resistência a sinais de apoptose e bloqueio na maturação desses progenitores linfóides (PUI; JEHA, 2007).

A influência dos eventos genéticos in utero envolvidos na leucemogênese é reforçada pela alta concordância das leucemias em gêmeos idênticos (BELSON; KINGSLEY; HOLMES, 2007; DOWNING; SHANNON, 2002; KEBRIAEI, 2003). Sabe-se também, que indivíduos com certas síndromes genéticas hereditárias e alterações cromossômicas como translocações e aneuploidias, apresentam um risco maior de desenvolver leucemia (BELSON; KINGSLEY; HOLMES, 2007). Entre essas alterações genéticas podemos citar a Síndrome de Down, Ataxia-Telangiectasia (KEBRIAEI, 2003), Anemia de Fanconi, Síndrome de Bloom, Síndrome de Shwachman e Neurofibromatose. Entretanto crianças com histórico familiar de outros tipos de câncer que não sejam neoplasias hematológicas, não apresentam um risco aumentado de adquirir LLA (BELSON; KINGSLEY; HOLMES, 2007).

Atualmente estão descritas diversas anormalidades cromossômicas e moleculares associadas a LLA que podem apresentar uma influência significativa 
no prognóstico. Experimentos in vitro revelaram que blastos hiperdiplóides, com mais de 50 cromossomos têm mostrado maior sensibilidade a quimioterápicos apresentando conseqüentemente um elevado índice de apoptose (CARROL et al., 2003) e pacientes com hiperdiploidia apresentam um prognóstico favorável. Por outro lado, a presença de blastos hipodiplóides com menos de 45 cromossomos é considerada um fator prognóstico desfavorável (CARROL et al., 2003; PUI; EVANS, 2006).

As alterações cromossômicas estruturais também são comuns na LLA. Nesta neoplasia, aproximadamente um terço dos blastos apresentam translocações cromossômicas, que muitas vezes definem subgrupos únicos de pacientes. A translocação cromossômica mais comum na LLA é a t(12;21) observada em mais de $25 \%$ dos casos de LLA tipo B (CARROL et al., 2003) sendo muito mais freqüente em crianças do que em adultos (PUI; EVANS, 2006). Essa translocação confere um bom prognóstico e resulta em uma fusão entre os genes TEL e $A M L 1$ (CARROL et al., 2003; PUI, 2004; PUI; EVANS, 2006).

A t $(1 ; 19)$ também é comum no subtipo pré-B; caracteriza-se pela fusão dos genes $E 2 A$ e $P B X$ e apresenta um impacto prognóstico adverso. Translocações envolvendo a região 11q23 onde se localiza o gene $M L L$ (mixed lineage laukemia) estão presentes em aproximadamente $6 \%$ dos casos de LLA, (CARROL et al., 2003) e entre essas translocações, são comuns as t(4;11) que resulta no gene de 
fusão $M L L-A F 4$, sendo muito freqüente em lactentes e a $t(11 ; 19)$, característica da LLA-T, resulta na fusão dos genes $M L L-E N L$ e uma expressão aumentada do gene HOX11 (PUI; EVANS, 2006). A presença do cromossomo Philadelphia resultante da $t(9 ; 22)$ é observada em cerca de $3 \%$ a $4 \%$ dos casos pediátricos de LLA e $20 \%$ dos casos em adultos (CARROL et al., 2003; PUI; EVANS, 2006). Em relação ao impacto prognóstico dessa translocação, parece haver uma melhora com o decréscimo da idade (PUI; EVANS, 2006).

Esses rearranjos cromossômicos são considerados eventos importantes, no entanto são geralmente insuficientes para provocar a transformação leucêmica e requerem alterações genéticas adicionais. (PUI, 2004; PUI; JEHA, 2007). Entre estas alterações adicionais, freqüentemente observa-se uma expressão aumentada do gene FTL3 no rearranjo MLL (mixed lineage leukemia) ou hiperdiploidia na LLA-B, mutações ativadoras do NOTCH1 na LLA-T, mutações em componentes de mecanismos inter-relacionados controlados pela proteína retinoblastoma supressora de tumor, proteínas relacionadas como p130, p170 e p53 (PUI; JEHA, 2007).

Em relação ao impacto no prognóstico dos pacientes, é importante ressaltar que as características do hospedeiro como a farmacodinâmica, farmacogenética e polimorfismos de genes envolvidos no transporte e metabolismo de drogas também podem influenciar a eficácia do tratamento (EVANS; 
MACLEOD, 2003; EVANS; RELLING, 2004). Um risco aumentado para o desenvolvimento da leucemia infantil tem sido associado recentemente a polimorfismos de genes envolvidos no metabolismo e transporte de xenobióticos (RUBNITZ; PUI, 2003; CANALLE et al., 2004).

Apesar da identificação de diversas alterações genéticas que podem apresentar importância em relação ao prognóstico dos pacientes com LLA, a idade e a contagem de leucócitos ao diagnóstico continuam sendo um dos fatores mais importantes. Muitos grupos de pesquisa estratificam os pacientes portadores de LLA em risco básico e alto. Pacientes com idade entre 1 e 10 anos e a presença de menos de $50 \times 10^{9}$ blastos por litro de sangue, normalmente são inclusos no grupo de risco básico, enquanto que os demais pacientes são considerados de alto risco (SMITH et al., 1996; RUBNITZ; PUI, 1997; REICHMANN, 2000; PUI; EVANS, 2006). A Tabela 1 mostra o esquema de classificação de risco da WHO (World Health Organization) em pacientes portadores de LLA.

Tabela 1 - Esquema de classificação de risco da WHO em pacientes com LLA

\begin{tabular}{ccc}
\hline Idade & Contagem inicial de GB & Grupo de Risco \\
\hline$<1$ ano & - & Alto risco \\
$1-9$ anos & $\geq 50.000$ por $\mu \mathrm{L}$ & Alto risco \\
$1-9$ anos & $<50.000$ por $\mu \mathrm{L}$ & Risco básico \\
$\geq 10$ anos & - & Alto risco \\
\hline
\end{tabular}

Abreviaturas: $\mathbf{G B}=$ Glóbulos Brancos; $\boldsymbol{\mu} \mathbf{L}=$ microlitros. SMITH 1996 
Apesar de vários grupos de estudo utilizarem esta classificação, há uma tendência de uma estratificação maior desses grupos de risco (PUI; EVANS, 2006).

A análise da Doença Residual Mínima (DRM) também tem mostrado ser um fator prognóstico importante no tratamento da LLA. A DRM pode ser definida como doença submicroscópica detectada nos pacientes em remissão clínica completa (GAYNON et al., 2000; MOPPETT et al. 2003; SCRIDELI et al., 2002; VAN DER VELDEN et al., 2003).

O sucesso no tratamento da LLA tem aumentado consideravelmente nas últimas décadas (PUI, 2004; PUI; EVANS, 2006) e com as novas estratégias de tratamento obteve-se uma taxa de cura de mais de $80 \%$ para os pacientes pediátricos. Entretanto em adultos essa taxa permanece próxima de $40 \%$. Além disso, muitos pacientes sofrem recaída da doença e desenvolvem sérias complicações decorrentes dos efeitos colaterais do tratamento. Assim, as novas estratégias no tratamento podem aumentar os índices de cura e melhorar a qualidade de vida dos pacientes (PUI; JEHA, 2007). Entre estas estratégias incluise uma classificação mais precisa dos grupos de risco, o melhoramento das terapias atuais por estudos de farmacodinâmica e farmacogenômica, e o desenvolvimento de terapias específicas (RUBNITZ; PUI, 2003). 
Recentemente drogas epigenéticas como inibidores de DNA metiltransferases e inibidores de histonas desacetilases (iHDAC) têm sido utilizadas com sucesso em triagens clínicas (PUI; JEHA, 2007).

\subsection{EPIGENÉTICA}

\subsubsection{Epigenética: Conceitos Gerais}

O termo epigenética refere-se a mecanismos herdáveis e potencialmente reversíveis que provocam alterações na expressão gênica sem que ocorram modificações na seqüência do DNA (ADCOCK et al., 2006; GALM; HERMAN; BAYLIN, 2006; KURDISTANI, 2007; LEHMANN; BRAKENSIEK; KREIPE, 2004; WEINHOLD, 2006). Esses mecanismos são essenciais para os processos de diferenciação e memória celular (DUCASSE; BROWN, 2006). Consequentemente a regulação epigenética é importante para manter a estabilidade do perfil de expressão gênica nos diversos tipos celulares e o entendimento dos mecanismos básicos que mediam essa regulação é fundamental para a compreensão dos processos de diferenciação celular e programação genômica (ADCOCK et al., 2006; GALLINARI et al., 2007). 
De modo geral, os principais mecanismos epigenéticos são representados basicamente pela metilação do DNA e pelas modificações das proteínas histonas (BERNSTEIN; MEISSNER; LANDER, 2007; DUCASSE; BROWN, 2006; LU et al., 2006; ROPERO; ESTELLER, 2007). Recentemente foi descrito também um processo de silenciamento epigenético mediado por RNA (ADCOCK et al., 2006).

A metilação do DNA consiste na adição do radical metil no carbono 5 do anel pirimídico da base citosina (C) seguida da base guanina (G), ou seja, em pontos conhecidos como dinucleotídeos CpG (BERNSTEIN; MEISSNER; LANDER, 2007; LEHMANN; BRAKENSIEK; KREIPE; 2004). Esse processo é catalisado e mantido num estado hereditário por um grupo de enzimas conhecidas como DNA metiltransferases (DNMTs) (ADCOCK et al., 2006; DUCASSE; BROWN, 2006). A metilação do DNA resulta no recrutamento de proteínas que restringem o acesso da maquinaria envolvida na transcrição gênica impedindo a realização desse processo (DUCASSE; BROWN, 2006; FEINBERG; TYCKO, 2004).

Estima-se que mais de $80 \%$ dos dinucleotídeos CpG encontram-se metilados no genoma dos mamíferos. Por outro lado, determinadas regiões ricas em dinucleotídeos $\mathrm{CpG}$ conhecidas como "ilhas $\mathrm{CpG}$ ”, na maioria das vezes não estão metiladas. Essas regiões geralmente apresentam mais de 500 pares de base com a maioria dos nucleotídeos contendo as bases nitrogenadas $\mathrm{C}$ e $\mathrm{G}$. As ilhas $\mathrm{CpG}$ estão 
localizadas próximas à regiões promotoras de mais da metade dos genes no genoma e quando são metiladas, a transcrição é impedida (ADCOCK et al., 2006; GALM; HERMAN; BAYLIN, 2006; JONES; BAYLIN, 2002).

Outro evento epigenético importante são os mecanismos que regulam a conformação da estrutura da cromatina por modificações químicas nas proteínas histonas que afetam a acessibilidade dos fatores de transcrição ao DNA. Estima-se que as proteínas histonas que compõem o nucleossomo estão sujeitas a mais de 100 modificações pós-traducionais, entretanto a grande maioria dessas modificações são pouco conhecidas. Apesar disso, nos últimos anos houve um considerável progresso na compreensão dos processos de metilação e acetilação dos resíduos de lisinas das histonas (BERNSTEIN; MEISSNER; LANDER, 2007).

A metilação dos resíduos de lisina das histonas pode resultar em diferentes efeitos em relação à atividade transcricional dependendo do resíduo modificado (BERNSTEIN; MEISSNER; LANDER, 2007; GALM; HERMAN; BAYLIN, 2006). Por outro lado, o processo de acetilação histonas tem sido tradicionalmente relacionado à acessibilidade dos fatores de transcrição a cromatina e ativação de mecanismos transcricionais (GALM; HERMAN; BAYLIN, 2006; MINUCCI; PELICCI, 2006). Desta forma, a metilação do DNA e as modificações nas histonas interagem num contexto de modificações epigenéticas apresentando 
um impacto significativo na estrutura da cromatina e na atividade transcricional (GALM; HERMAN; BAYLIN, 2006).

\subsubsection{Epigenética e Câncer}

Além das alterações genéticas, tem se tornado cada vez mais evidente que as alterações nas informações epigenéticas estão profundamente relacionadas ao processo de carcinogênese (BAYLIN; OHM, 2006; DUCASSE; BROWN, 2006; GALM; HERMAN; BAYLIN, 2006; MIYAMOTO; USHIJIMA, 2005; TING; MCGARVEY; BAYLIN, 2006). Essas alterações epigenéticas podem se manifestar provocando mudanças globais na estrutura da cromatina ou podem provocar mudanças em promotores de determinados genes envolvidos no controle do ciclo celular alterando a atividade transcricional (LU et al., 2006; TING; MCGARVEY; BAYLIN, 2006).

As alterações no padrão de metilação do DNA tem sido frequentemente associadas ao processo de carcinogênese (ESTELLER, 2006; GALM; HERMAN; BAYLIN, 2006; LU et al., 2006; MIYAMOTO; USHIJIMA, 2005). Uma característica comum das neoplasias humanas inclui a perda da metilação genômica do DNA e a hipermetilação de ilhas CpG localizadas em regiões promotoras de 
genes supressores tumorais (ESTELLER, 2006; GALM; HERMAN; BAYLIN, 2006; JONES; BAYLIN, 2002; TING; MCGARVEY; BAYLIN, 2006). Estas alterações contribuem para uma mudança na estrutura da cromatina que pode resultar na transcrição inapropriada de elementos repetitivos, instabilidade genômica e no silenciamento anormal de genes importantes na iniciação e progressão de tumores (LU et al., 2006, TING; MCGARVEY; BAYLIN, 2006). Acredita-se que muitas vezes, a perda de função de determinados genes no câncer podem apresentar mais causas epigenéticas do que genéticas (JONES; BAYLIN, 2002; TING; MCGARVEY; BAYLIN, 2006).

Por exemplo, a hipótese dos dois eventos de inativação dos genes supressores de tumor proposta por Knudson (KNUDSON, 1971), em geral requer a perda de função das duas cópias do gene. Nesse contexto, a hipermetilação anormal da região promotora de um gene, pode exercer o mesmo efeito de uma deleção ou de uma mutação em um dos alelos (GALM; HERMAN; BAYLIN, 2006; JONES; BAYLIN, 2002). De fato, qualquer tipo de câncer pode apresentar simultaneamente o silenciamento epigenético de muitos genes supressores de tumor, genes de reparo no DNA, genes envolvidos no controle do ciclo celular e apoptose (BAYLIN; OHM, 2006; TING; MCGARVEY; BAYLIN, 2006).

Esse controle epigenético da expressão gênica pode se encontrar alterado durante a embriogênese podendo resultar em uma predisposição ao câncer 
pediátrico ou pode ser alterado durante o desenvolvimento pós-natal aumentando o risco de câncer em adultos (FEINBERG; TYCKO, 2004). Além disso, vários genes submetem se a perda do imprinting resultando na expressão anormal dos dois alelos (TING; MCGARVEY; BAYLIN, 2006). Alguns estudos indicam que as alterações epigenéticas podem também induzir a um estágio pré-maligno em etapas precoces do processo de carcinogênese propiciando o surgimento de alterações genéticas subseqüentes que possibilitam a proliferação e crescimento tumoral (BAYLIN; OHM, 2006).

Desta forma, o conhecimento de alterações epigenéticas específicas em tecidos neoplásicos pode ser aplicado ao diagnóstico do câncer. Além disso, determinadas alterações observadas em tecidos não neoplásicos podem ser utilizadas como marcadores de risco além de possibilitar a identificação de genes que possivelmente estariam envolvidos nos eventos de iniciação e progressão de tumores (BAYLIN; OHM, 2006; ESTELLER, 2006). 


\subsection{HISTONAS DESACETILASES}

\subsubsection{Cromatina e a Acetilação das Histonas}

Em eucariotos, as histonas são as proteínas mais abundantes associadas ao DNA. Essas proteínas são ricas em aminoácidos de carga positiva que interagem com a carga negativa dos grupamentos fosfatos presentes no DNA. Juntamente com o DNA, as proteínas histonas constituem o nucleossomo, que é a unidade estrutural da cromatina (ACHARYA et al., 2005; MINUCCI; PELICCI, 2006). Cada nucleossomo é formado por 146 pares de nucleotídeos envolvidos 1,7 vezes (DUCASSE; BROWN, 2006) em torno de um octâmero de histonas, composto por duas cópias de cada uma das histonas H2A, H2B, H3 e H4 (ADCOCK et al., 2006; ACHARYA et al., 2005; CRESS; SETO, 2000; DUCASSE; BROWN, 2006; LU et al., 2006; MARKS et al., 2001; RUIJTER et al., 2003). Os nucleossomos são unidos entre si por uma região que apresenta aproximadamente 50 pares de bases (DUCASSE; BROWN, 2006), sendo que esta região está geralmente associada à histona H1 (CRESS; SETO, 2000; KIMMINS; SASSONE-CORSI, 2005; LUND; van LOHUIZEN, 2004) que também é importante para determinar o nível de condensação do DNA, mas não é regulada pelo processo de acetilação (MARKS et al., 2001). 
A estrutura das histonas é altamente conservada durante o processo evolutivo indicando um papel importante nos mecanismos básicos na célula (CRESS; SETO, 2000, DUCASSE; BROWN, 2006; MARKS et al., 2001, MINUCCI; PELICCI, 2006). Estas proteínas apresentam um domínio que mantém um intenso contato com o DNA e resíduos de aminoácidos que se estendem a uma distância maior do centro do nucleossomo (GALLINARI et al., 2007; MINUCCI; PELICCI, 2006). As histonas H2A, H2B, H3 e H4 possuem um grupamento amino-terminal (N-terminal) contendo diversos resíduos de aminoácidos conservados, principalmente resíduos de lisina (lis), serina (ser) e arginina (arg). Esses resíduos são sítios das principais modificações pós-traducionais que ocorrem nas histonas, tais como: fosforilação (ser), metilação (lis ou arg), ADP-ribosilação, ubiquitinação (lis) e acetilação (lis) (ACHARYA et al., 2005; GALLINARI et al., 2007; KIMMINS; SASSONE-CORSI, 2005; LU et al., 2006; LUND; van LOHUIZEN, 2004).

A interação das histonas com a região polianiônica do DNA, representada pelos grupos fosfato, resulta em uma estabilidade do nucleossomo. Essas interações são formadas primariamente por pontes de hidrogênio entre a cadeia principal das histonas e o oxigênio do grupo fosfato do DNA (DUCASSE; BROWN, 2006). 
As modificações pós-traducionais nas histonas podem ocorrer isoladamente ou de forma combinada afetando a acessibilidade de fatores nucleares ao DNA ou podem induzir o recrutamento de tais fatores envolvidos na transcrição. Desta forma, o padrão de modificações nas histonas determina o status da cromatina (CRESS; SETO, 2000, LUND; van LOHUIZEN, 2004) e entre os diversos tipos de modificações pós-traducionais, a acetilação das histonas é a modificação mais bem caracterizada e desempenha um papel crucial na modulação da expressão gênica (CRESS; SETO, 2000; ROPERO; ESTELLER, 2007).

No início da década de 60, Alfrey, Faulkner e Mirsky (1964), relataram uma correlação entre o aumento nos níveis de acetilação das histonas e um aumento na atividade transcricional. Atualmente sabe se que essas modificações nas caudas n-terminais das histonas pela acetilação e desacetilação são fundamentais na modulação da expressão gênica por afetarem as interações das histonas com o DNA juntamente com outros complexos protéicos reguladores da transcrição. Duas classes de enzimas estão envolvidas no processo de acetilação das histonas; as Histonas Acetil Transferases (HATs) e as Histonas Desacetilases (HDACs) (ACHARYA et al., 2005; MARKS et al., 2001, MARKS; MILLERY; RICHONY, 2003, RUIJTER et al., 2003). No processo de acetilação das histonas as HATs atuam preferencialmente modificando substratos específicos de lisina das histonas além de outras proteínas não-histonas e fatores de transcrição afetando as 
propriedades de ligação ao DNA (ACHARYA et al., 2005; ROPERO; ESTELLER, 2007). Em geral, o aumento dos níveis de acetilação de histonas está associado a um aumento da atividade transcricional (ACHARYA et al., 2005; GALLINARI et al., 2007; MARKS; MILLERY; RICHONY, 2003; RUIJTER et al., 2003; ROPERO; ESTELLER, 2007).

A atividade das HDACs envolve a remoção de grupos acetil dos resíduos de lisina das histonas restabelecendo a carga positiva dessas proteínas. Consequentemente esses resíduos de lisina sofrem uma forte atração pelos grupos fosfatos do DNA resultando na compactação da cromatina que impede a ligação de fatores de transcrição, complexos regulatórios e da RNA polimerase impedindo a transcrição (ACHARYA et al., 2005; ROPERO; ESTELLER, 2007). Adicionalmente a essas alterações eletrostáticas na cromatina, as HATs e HDACs estão envolvidas no recrutamento de complexos co-ativadores e co-repressores da transcrição (ADCOCK et al., 2006, DUCASSE; BROWN, 2006; GALLINARI et al., 2007).

Desta foram, as HATs e HDACs atuam de forma orquestrada ordenando o padrão de expressão gênica nos diferentes tecidos. O silenciamento inapropriado de genes críticos pelas HDACs, pode resultar na inativação de genes supressores tumorais e contribuir para o desenvolvimento e transformação neoplásica 
(ACHARYA et al., 2005; GALLINARI et al., 2007; MAHLKNECHT; OTTMANN; HOELZER, 2000; ROPERO; ESTELLER, 2007).

\subsubsection{Classificação das HATs e HDACs}

Recentemente foram identificados vários grupos distintos de proteínas com atividade acetil-transferase que são divididas em cinco famílias distintas: a família GNAT (Gcn5-realated acetyltransferase); a família MYST (MOZ, Ybf2/Sas3, Sas2, Tip60-related); a família p300/CBP (CREB-binding protein); a família General Transcription Factor HATs e a família Nuclear Hormones Related HATs (ADCOCK et al., 2006; ROTH; DENU; ALLIS, 2001). Em geral, a atividade das HATs, está associada à complexos protéicos que incluem outras HATs e coativadores de fatores de transcrição (ACHARYA et al., 2005; CHEN; TINI; EVANS, 2001; ROTH; DENU; ALLIS, 2001). Sabe-se também que além das histonas, as HATs apresentam outros substratos como proteínas não histonas e fatores de transcrição (GALLINARI et al., 2007; ROTH; DENU; ALLIS, 2001). Entre esses substratos incluem genes envolvidos no controle do ciclo celular como o E2F, p53 e GATA1. Assim não é surpreendente que a atividade alterada das 
HATs tenha sido observada em vários tipos de câncer (ACHARYA et al., 2005; CHEN; TINI; EVANS, 2001).

A primeira HDAC identificada em mamíferos apresentava alta similaridade com um regulador transcricional de leveduras (Saccharomyces cerevisiae) conhecido como Rpd3. Posteriormente diversas outras HDACs foram identificadas e classificadas de acordo com a filogenia e com as formas homólogas em leveduras (DUCASSE; BROWN, 2006; GALLINARI et al., 2007; MARKS, 2007). Atualmente as HDACs estão divididas em 4 classes (ADCOCK et al., 2006; GALLINARI et al., 2007).

As HDACs de classe I (HDAC 1, 2, 3 e 8) são proteínas com pesos moleculares que variam de 22-55 $\mathrm{kDa}$ apresentando homologia em seus sítios catalíticos (MARKS, 2007). São similares a Rpd3 de leveduras, apresentam localização nuclear e mostram uma expressão ampla nos diversos tecidos (ACHARYA et al., 2005; MINUCCI; PELICCI, 2006).

As HDACs da classe II $(4,5,6,7,9 \mathrm{a}, 9 \mathrm{~b}$ e 10) são moléculas maiores com pesos moleculares variando de 120-135 kDa (MARKS, 2007). São homólogas a Hda1 de leveduras, apresentam localização nuclear e citoplasmática e a distribuição é limitada a alguns tecidos (ACHARYA et al., 2005, MINUCCI; PELICCI, 2006). As HDACs 6 e 10 são as únicas a apresentarem 2 domínios catalíticos (MARKS, 2007). As HDACs de Classe II podem ser subdivididas em 
duas subclasses: IIa (HDAC 4, 7 e 9) e IIb (HDAC 6 e 10) (ROPERO; ESTELLER, 2007).

A classe III das HDACs consiste na família das sirtuínas (Sirt1, 2, 3, 4, 5, 6 e 7) conhecidas como SIR (silent information regulators), semelhantes a proteína Sir2 de leveduras, são evolutivamente distintas das outras classes e apresentam um mecanismo enzimático dependente de $\mathrm{NAD}^{+}$(ACHARYA et al., 2005; MINUCCI; PELICCI, 2006). Sabe-se pouco sobre as HDACs de classe 3, entretanto acredita-se que essas enzimas estão relacionadas com a regulação dos níveis de NAD no metabolismo energético (GALLINARI et al., 2007).

A classe IV é representada pela HDAC11 (ADCOCK et al., 2006; SENESE et al., 2007) que é uma enzima com propriedades intermediárias entre as da classe I e II das HDACs (DRUMMOND et al., 2005; DUCASSE; BROWN, 2006; MARKS, 2007). No entanto, esta classe é filogeneticamente diferente das HDACs de classe I e II (GALLINARI et al., 2007). Um componente essencial para a atividade das HDACs de classe I, II e IV é a presença de Zinco $\left(\mathrm{Zn}^{2+}\right)$ (MINUCCI; PELICCI, 2006; RUIJTER et al., 2003). A Tabela 2 mostra a classificação das HDACs, a localização subcelular, os principais tecidos humanos onde cada uma é expressa e a similaridade de cada uma com suas formas homólogas em leveduras. 
Tabela 2 - Classificação das Histonas Desacetilases

\begin{tabular}{|c|c|c|c|c|}
\hline Enzima & Classe & Localização & Expressão nos tecidos & Similaridade \\
\hline HDAC 1 & I & Núcleo & Maioria & $\begin{array}{c}\text { RPD3 } \\
\text { (levedura) }\end{array}$ \\
\hline HDAC 2 & I & Núcleo & Maioria & $\begin{array}{c}\text { RPD3 } \\
\text { (levedura) }\end{array}$ \\
\hline HDAC 3 & I & $\begin{array}{l}\text { Núcleo } \\
\text { (maioria) }\end{array}$ & Maioria & $\begin{array}{c}\text { RPD3 } \\
\text { (levedura) }\end{array}$ \\
\hline HDAC 8 & I & Núcleo & Maioria & $\begin{array}{c}\text { RPD3 } \\
\text { (levedura) }\end{array}$ \\
\hline HDAC 4 & IIa & $\begin{array}{l}\text { Núcleo e } \\
\text { citoplasma }\end{array}$ & $\begin{array}{l}\text { Cérebro, coração, músculo } \\
\text { esquelético }\end{array}$ & $\begin{array}{l}\text { HDAC1 } \\
\text { (levedura) }\end{array}$ \\
\hline HDAC 5 & IIa & $\begin{array}{l}\text { Núcleo e } \\
\text { citoplasma }\end{array}$ & $\begin{array}{c}\text { Cérebro, coração, músculo } \\
\text { esquelético }\end{array}$ & $\begin{array}{l}\text { HDAC1 } \\
\text { (levedura) }\end{array}$ \\
\hline HDAC 6 & $\mathrm{IIb}$ & Citoplasma & Timócitos, coração, pulmão & $\begin{array}{l}\text { HDAC1 } \\
\text { (levedura) }\end{array}$ \\
\hline HDAC 7 & IIa & $\begin{array}{l}\text { Núcleo e } \\
\text { citoplasma }\end{array}$ & $\begin{array}{c}\text { Cérebro, coração, músculo } \\
\text { esquelético }\end{array}$ & $\begin{array}{l}\text { HDAC1 } \\
\text { (levedura) }\end{array}$ \\
\hline HDAC 9a & IIa & $\begin{array}{l}\text { Núcleo e } \\
\text { citoplasma }\end{array}$ & Fígado, baço, rim & $\begin{array}{l}\text { HDAC1 } \\
\text { (levedura) }\end{array}$ \\
\hline HDAC 9b & IIa & $\begin{array}{l}\text { Núcleo e } \\
\text { citoplasma }\end{array}$ & $? ? ?$ & $\begin{array}{l}\text { HDAC1 } \\
\text { (levedura) }\end{array}$ \\
\hline HDAC 10 & $\mathrm{IIb}$ & Citoplasma & Testículos, outros & $\begin{array}{l}\text { HDAC1 } \\
\text { (levedura) }\end{array}$ \\
\hline SirT 1 a 7 & III & $? ? ?$ & $? ? ?$ & Sir2 (levedura) \\
\hline HDAC 11 & IV & $\begin{array}{l}\text { Núcleo } \\
\text { (maioria) }\end{array}$ & $\begin{array}{l}\text { Rim, coração, cérebro, } \\
\text { testículos, músculo } \\
\text { esquelético }\end{array}$ & $? ? ?$ \\
\hline
\end{tabular}


É importante ressaltar que muitas vezes as HDACs fazem parte de complexos multi-proteicos e a atividade dessas enzimas depende de outros fatores como co-repressores transcricionais (mSin3, N-CoR e SMART). Esses complexos são recrutados para regiões específicas do genoma por interações com fatores de ligação ao DNA que incluem fatores de transcrição, receptores nucleares e genes envolvidos em outras modificações epigenéticas como metil-binding protein (MBDs), DNA metil-transferases (DNMTs) e histonas metil-transferases (HMTs) (ROPERO; ESTELLER, 2007). Neste caso, qualquer alteração na atividade desses fatores pode influenciar de forma indireta a atividade das HDACs e a transcrição gênica.

\subsubsection{Histonas Desacetilases e Câncer}

A identidade de uma célula é definida pelo padrão característico de expressão e silenciamento de seus genes (TURNER, 2002). Além disso, muitas vezes, a regulação anormal da expressão gênica é considerada a base de diversas patologias humanas incluindo várias formas de câncer (GALLINARI et al., 2007, ROPERO; ESTELLER, 2007). Assim, a acetilação das histonas torna-se um componente essencial na modulação da expressão gênica. Atualmente sabe-se que 
as HDACs estão envolvidas na proliferação, diferenciação e controle do ciclo celular (ACHARYA et al., 2005; MARKS; MILLERY; RICHONY, 2003; MINUCCI; PELICCI, 2006) e vários estudos vem demonstrando uma relação importante entre a expressão anormal das HDACs e o desenvolvimento de vários tipos de câncer (ACHARYA et al., 2005; GALLINARI et al., 2007; MINUCCI; PELICCI, 2006; ROPERO; ESTELLER, 2007; RUIJTER et al., 2003).

Além das histonas, proteínas não-histônicas e várias proteínas citoplasmáticas também são controladas pela atividade das HATS e HDACs (MARKS; MILLERY; RICHONY, 2003; MINUCCI; PELICCI, 2006; ROPERO; ESTELLER, 2007). Um exemplo típico é o inibidor de quinase dependente de ciclina $\mathrm{p} 21^{\mathrm{WAF} 1}$, que inibe a progressão do ciclo celular e cujo gene não é expresso em diferentes tipos de tumor. Em alguns casos o $p 21^{\text {WAFl }}$ é inativado epigeneticamente pela desacetilação de seu promotor, e o tratamento com iHDAC resulta na inibição do crescimento celular e na reativação da expressão desse gene (GUI et al., 2004). Sabe-se também que o recrutamento aberrante das HDACs para regiões promotoras do gene da E-Caderina está associado à invasão e metástase (YANG; ZHANG; KUMAR 2005).

As alterações na expressão e atividade de HATS e HDACs tem sido observado em tumores sólidos. Além disso, esses estudos mostraram uma relação entre a diminuição na taxa de acetilação de histonas e resultados clínicos. Outros 
estudos relacionados à patogenia molecular em LMA têm mostrado que níveis anormais de HDACs desempenham um papel importante no desenvolvimento da leucemia (FENRICK; HIEBERT, 1998; MINUCCI; PELICCI, 2006).

Sabe-se que eventos moleculares importantes envolvidos na patogênese da Leucemia Promielocítica Aguda (LPA) resultam no recrutamento anormal das HDACs, que atualmente são consideradas um alvo molecular comum na terapia de diferenciação em LMA (MINUCCI et al., 2001; MINUCCI; PELICCI, 2006). A LPA foi o primeiro modelo em que foi demonstrado o envolvimento das HDACs na patogênese de uma neoplasia (FEINRICK; HIEBERT, 1998; MINUCCI et al., 2001). Essa forma de leucemia é caracterizada pela presença de proteínas de fusão envolvendo o receptor- $\alpha$ de ácido retinóico (RAR) resultando em um bloqueio na diferenciação de células da linhagem mielóide. Esses rearranjos envolvendo o $R A R$ resultam em interações anormais com co-reguladores transcricionais como NCoR (nuclear co-repressor) e SMRT (silencing mediator of retinoic acid and thyroid hormone receptors) responsáveis pelo recrutamento das HDACs. Desta forma, na presença desses rearranjos, níveis físiológicos de ácido retinóico (AR) não são suficientes para promover a diferenciação dos blastos em granulócitos maduros (FEINRICK; HIEBERT, 1998; MINUCCI et al., 2001; MINUCCI; PELICCI, 2006). 
Em mais de $90 \%$ dos casos de LPA a proteína envolvida na fusão com o $R A R$, é a $P M L$ (promyelocytic leukaemia). Em 5\% observa-se a fusão entre $R A R$ e PLZF (promyelocytic leukaemia zinc finger) e esporadicamente o RAR está envolvido na fusão com outros genes. Clinicamente os pacientes que expressam $P M L-R A R$ respondem a níveis farmacológicos de AR que são suficientes para a dissociação de PML-RAR e NCor/SMRT-HDAC possibilitando a diferenciação. Por outro lado, pacientes com a fusão $P L Z F-R A R$ não respondem ao tratamento com AR. Nesse caso a combinação de AR com iHDAC resulta na diferenciação dos blastos e é extremamente efetivo no tratamento da LPA (MINUCCI; PELICCI, 2006). Um mecanismo similar é também observado em LMA com a presença da t $(8 ; 21)$ e formação da proteína de fusão AML1-ETO que provoca um bloqueio na via de sinalização do AR (MINUCCI et al., 2001; ROPERO; ESTELLER, 2007).

Atualmente as HDACs são consideradas um dos alvos mais promissores para o desenvolvimento de drogas utilizadas na terapia contra o câncer (MINUCCI; PELICCI, 2006), e os iHDAC fazem parte de uma nova classe de agentes que atuam sobre a regulação da expressão gênica e tem mostrado diversos efeitos anticâncer, como parada do crescimento celular, diferenciação e potencial para indução de apoptose em diversos tipos de neoplasias (BERNHARD et al., 2001; BI; JIANG, 2006; DRUMMOND et al., 2005; MARKS; RICHON; RIFKIND, 2000; MINUCCI; PELICCI, 2006; PARK et al., 2004; ROMANSKI et al., 2004). Um 
fato interessante sobre os iHDAC é que em alguns casos, células neoplásicas são mais sensíveis aos seus efeitos quando comparadas a células de tecido não neoplásico (MINUCCI; PELICCI, 2006, SENESE et al., 2007).

Apesar da observação de todos estes efeitos anticâncer, alguns estudos referentes a alterações na expressão gênica em culturas de células neoplásicas, mostram que apenas um pequeno número de genes tem expressão alterada quando as culturas são tratadas com iHDAC. Esses dados indicam que os iHDAC provocam ativação de um número selecionado de genes cuja expressão provoca inibição do crescimento das células neoplásicas (DRUMMOND et al., 2005; MARKS; MILLERY; RICHONY, 2003). Acredita se que os efeitos anticâncer dos iHDAC resultam da reativação de genes supressores de tumor (ESTELLER, 2006).

Embora a base molecular do funcionamento dos iHDAC ainda não seja bem compreendida, estudos clínicos demonstram que essas drogas, combinadas com outros agentes terapêuticos, são de fato, clinicamente ativas e muito bem toleradas no tratamento de uma grande variedade de tumores (BI; JIANG, 2006; DRUMMOND et al., 2005; MINUCCI; PELICCI, 2006). Entretanto, os efeitos dos iHDAC são diferentes para cada tipo de linhagem celular, e além disso, dependem também do tipo de droga utilizada e do tempo de exposição (BI; JIANG, 2006). 
Até o momento foram identificadas 18 enzimas com atividade desacetilases nos mamíferos (BI; JIANG, 2006; ROPERO; ESTELLER, 2007), e estudos recentes utilizando técnicas do siRNA (small interfering $R N A$ ), sugerem que as HDACs de Classe I podem ser um dos alvos mais relevantes para a intervenção em oncologia (ACHARYA et al., 2005; CURTIN; GLASER, 2003).

Cada vez tem se tornado mais evidente o papel importante das HDACs no desenvolvimento de tumores sólidos e de neoplasias hematológicas, principalmente na LPA. Recentemente foi demonstrado que alguns iHDAC induzem parada do ciclo celular e apoptose em culturas de células derivadas de pacientes portadores de LLA (ROMANSKI et al., 2004). Apesar disso, pouco se sabe a respeito da atividade das HDACs nesse tipo de neoplasia. 
2. OBJETIVOS 


\section{OBJETIVOS}

Avaliar a expressão dos genes da classe I de HDACs em 46 amostras de medula óssea de pacientes portadores de LLA utilizando a técnica PCR em Tempo Real.

Correlacionar os resultados da análise da expressão gênica com as características clínicas e de prognóstico (idade, gênero, grupo de risco, contagem inicial de blastos, imunofenótipo, presença de doença residual mínima e sobrevida livre de eventos) dos pacientes portadores de LLA.

Comparar a expressão dos genes de classe I das HDACs nas amostras dos pacientes com LLA com 10 amostras de medula óssea sem doença hematológica.

Analisar a existência de correlações entre a expressão dos genes de classe $I$ das HDACs. 
3. CASUÍSTICA 


\section{CASUÍSTICA}

Neste estudo foram incluídas 46 amostras consecutivas de medula óssea de crianças e adolescentes portadores de LLA, diagnosticadas e tratadas no Hospital das Clínicas da Faculdade de Medicina de Ribeirão Preto da Universidade de São Paulo (HC/FMRP-USP), no período de março 1998 a janeiro de 2006 e 10 amostras de doadores de medula óssea sem doença hematológica.

Dos 46 pacientes portadores de LLA, 23 pertenciam ao gênero masculino e 23 do gênero feminino. A idade ao diagnóstico variou de 7 a 189 meses. Em relação ao imunofenótipo, 40 casos foram provenientes de linhagem B (36 expressaram o antígeno CALLA) e 6 provenientes da linhagem T. Dos pacientes incluídos no estudo, 10 sofreram recaída ou óbito, 32 encontram-se em remissão clínica completa, 2 em tratamento e 2 foram transferidos para outras instituições. Quanto a contagem inicial de glóbulos brancos, 32 pacientes apresentaram uma quantidade menor que 50.000 por $\mu \mathrm{L}$ e 14 com quantidade maior ou igual 50.000 por $\mu \mathrm{L}$ ao diagnóstico.

As amostras dos pacientes com LLA fazem parte do Banco de Medula Óssea do Laboratório de Oncologia Pediátrica do HC/FMRP-USP e foram obtidas ao diagnóstico através de punção da crista ilíaca ou região pré-tibial. 
O diagnóstico dos pacientes foi realizado pelo laboratório de hematologia do HC/FMRP-USP baseado em critérios morfológicos e citoquímicos, através da imunofenotipagem por citometria de fluxo com anticorpos monoclonais do aspirado de medula óssea. Após a coleta, uma pequena alíquota de 0,5 a 1,0 mL deste material foi utilizada para estudos citogenéticos e moleculares realizados no laboratório de Oncologia Pediátrica do Departamento de Puericultura e Pediatria da FMRP-USP através das técnicas de RT-PCR e bandeamento GTG.

Os critérios adotados para inclusão dos pacientes no estudo foram a disponibilidade de amostras de medula óssea coletadas ao diagnóstico e com mais de $90 \%$ de células blásticas, criopreservadas a $-80^{\circ} \mathrm{C}$. Foram estudadas somente as amostras de medula óssea de crianças cujos pais ou responsáveis legais concordaram com a participação no estudo, formalizado através da assinatura do "Termo de Consentimento Livre e Esclarecido" (Anexo 1) aprovado pelo Comitê de Ética em Pesquisa de acordo com o Processo n 11750/2006 (Anexo 2).

Foram excluídas do estudo as amostras que apresentaram qualidade ou quantidade insatisfatória; amostras de crianças admitidas no HC/FMRP-USP para manutenção e cujo tratamento tenha sido iniciado em outra instituição; crianças portadoras de LLA de células B maduras e crianças cujos pais ou responsáveis legais não concordaram em participar do estudo. 
Todos os pacientes incluídos neste estudo foram tratados de acordo com protocolos terapêuticos propostos pelo Grupo Brasileiro de Tratamento da Leucemia da Infância - GBTLI (GRUPO BRASILEIRO DE TRATAMENTO DA LEUCEMIA INFANTIL, 1993; 1999). Foram considerados como de alto risco os pacientes que apresentaram pelo menos um dos seguintes critérios ao diagnóstico: idade igual ou superior a 9 anos ou inferior a 12 meses e/ou leucometria superior a 50.000/mm³ . Para o GBTLI 93 foram considerados também critérios para inclusão no grupo de alto risco de recaída: invasão de sistema nervoso central, presença de massa mediastinal e/ou hepatoesplenomegalia volumosa ao diagnóstico. Presença de imunofenótipo $\mathrm{T}$ e/ou achados desfavoráveis de citogenética também foram critérios recomendáveis para a caracterização dos pacientes de alto risco. Os pacientes que não apresentaram nenhum dos critérios mencionados acima foram considerados como de baixo risco de recaída ou de risco básico. Segundo esta estratificação de risco de recaída ao diagnóstico, a distribuição encontrada foi: 30 pacientes $(65,21 \%)$ pertenciam ao grupo de alto risco e 16 pacientes $(34,78 \%)$ ao grupo de baixo risco.

O estudo da detecção de doença residual mínima foi realizado através da PCR para rearranjos de Receptores de Células T (TCR) e da cadeia pesada de imunoglobulina (IgH) com primers de consenso ao final da indução de remissão (vigésimo oitavo dia de tratamento) da LLA sendo que a sensibilidade do método 
utilizado foi de uma célula leucêmica entre $10^{2}$ e $10^{3}$ células normais (SCRIDELI et al., 2003). As características clínicas e laboratoriais do diagnóstico dos pacientes incluídos neste estudo estão detalhadas na Tabela 3.

Tabela 3 - Características do diagnóstico e situação clínica atual dos pacientes com LLA avaliados e admitidos no Hospital das Clínicas da Faculdade de Medicina de Ribeirão Preto da Universidade de São Paulo (HC/FMRP-USP) no período de janeiro de 1998 a janeiro de 2006 .

\begin{tabular}{|c|c|c|c|c|c|c|c|c|}
\hline Paciente & Idade(m) & Sexo & GB & Risco & Imunofenótipo & Resposta & Situação Atual & SLE (m) \\
\hline 628 & 61 & $\mathrm{~F}$ & 2100 & B & PRÉ-B/CALLA+ & $\mathrm{R}$ & $\mathrm{RCC}(\mathrm{FT})$ & 111 \\
\hline 707 & 93 & $\mathrm{~F}$ & 4700 & B & PRÉ-B/CALLA+ & $\mathrm{R}$ & Recidiva & 51 \\
\hline 722 & 46 & $M$ & 12200 & B & PRÉ-B/CALLA+ & $\mathrm{R}$ & $\mathrm{RCC}(\mathrm{FT})$ & 109 \\
\hline 732 & 35 & $M$ & 16600 & $A$ & PRÉ-B/CALLA+ & $\mathrm{R}$ & Recidiva & 3 \\
\hline 741 & 76 & $\mathrm{~F}$ & 4900 & B & PRÉ-B/CALLA+ & $\mathrm{R}$ & $\mathrm{RCC}(\mathrm{FT})$ & 108 \\
\hline 874 & 9 & $\mathrm{~F}$ & 20600 & $A$ & PRÓ-B/CALLA- & NR & ÓBITO(rec) & 15 \\
\hline 931 & 31 & $\mathrm{~F}$ & 6200 & B & PRÉ-B/CALLA+ & $\mathrm{R}$ & Recidiva & 95 \\
\hline 972 & 32 & $M$ & 52100 & $A$ & PRÉ-B/CALLA+ & NR & RCC & 91 \\
\hline 1055 & 14 & $\mathrm{~F}$ & 2100 & B & PRÉ-B/CALLA+ & NR & $\mathrm{RCC}$ & 84 \\
\hline 1066 & 121 & $M$ & 500 & $A$ & PRÉ-B/CALLA+ & $\mathrm{R}$ & $\mathrm{RCC}(\mathrm{FT})$ & 83 \\
\hline 1069 & 7 & $M$ & 606400 & $A$ & PRÓ-B/CALLA- & $\mathrm{L}$ & ÓBITO(rec) & 0 \\
\hline 1111 & 79 & $\mathrm{~F}$ & 15900 & $A$ & CÉL-T/CALLA- & $\mathrm{L}$ & $\mathrm{RCC}(\mathrm{FT})$ & 79 \\
\hline 1128 & 119 & $M$ & 200600 & $A$ & CÉL-T/CALLA- & $\mathrm{R}$ & $\mathrm{RCC}(\mathrm{FT})$ & 79 \\
\hline 1130 & 41 & $M$ & 5500 & B & PRÉ-B/CALLA+ & $\mathrm{R}$ & $\mathrm{RCC}(\mathrm{FT})$ & 78 \\
\hline 1179 & 159 & $M$ & 117200 & $A$ & CÉL-T/CALLA- & $\mathrm{R}$ & $\mathrm{RCC}(\mathrm{FT})$ & 73 \\
\hline 1200 & 60 & $M$ & 58300 & $A$ & CÉL-T/CALLA- & $\mathrm{R}$ & $\mathrm{RCC}(\mathrm{FT})$ & 72 \\
\hline 1259 & 56 & $\mathrm{~F}$ & 1200 & $A$ & PRÉ-B/CALLA+ & $\mathrm{R}$ & $\mathrm{RCC}(\mathrm{FT})$ & 67 \\
\hline 1292 & 150 & $\mathrm{~F}$ & 630000 & $A$ & PRÓ-B/CALLA- & NR & ÓBITO & 0 \\
\hline 1325 & 11 & $M$ & 800 & $A$ & PRÉ-B/CALLA+ & $\mathrm{L}$ & ÓBITO & 0.3 \\
\hline 1328 & 152 & $M$ & 778000 & $A$ & PRÉ-B/CALLA+ & L & ÓBITO & 0 \\
\hline 1385 & 8 & $\mathrm{~F}$ & 68600 & $A$ & PRÓ-B/CALLA- & $\mathrm{L}$ & ÓBITO & 0 \\
\hline 1390 & 43 & $M$ & 10300 & B & PRÉ-B/CALLA+ & $\mathrm{R}$ & $\mathrm{RCC}(\mathrm{FT})$ & 57 \\
\hline 1418 & 39 & $\mathrm{~F}$ & 2200 & B & PRÉ-B/CALLA+ & $\mathrm{R}$ & $\mathrm{RCC}(\mathrm{FT})$ & 54 \\
\hline 1434 & 47 & $\mathrm{~F}$ & 68900 & $A$ & PRÉ-B/CALLA+ & $\mathrm{L}$ & $\mathrm{RCC}(\mathrm{FT})$ & 53 \\
\hline 1498 & 157 & $\mathrm{~F}$ & 13400 & $A$ & PRÉ-B/CALLA+ & $\mathrm{R}$ & $\mathrm{RCC}(\mathrm{ET})$ & 49 \\
\hline 1521 & 64 & $M$ & 14100 & B & PRÉ-B/CALLA+ & $\mathrm{R}$ & $\mathrm{RCC}(\mathrm{ET})$ & 48 \\
\hline
\end{tabular}




\section{Continuação}

\begin{tabular}{ccccclccc}
\hline Paciente & Idade $(\mathbf{m})$ & Sexo & GB & Risco & Imunofenótipo & Resposta & Situação Atual & SLE (m) \\
\hline 1535 & 189 & M & 2800 & A & PRÉ-B/CALLA+ & R & RCC(ET) & 47 \\
1572 & 26 & F & 45000 & B & PRÉ-B/CALLA+ & R & RCC(ET) & 45 \\
1574 & 20 & M & 86800 & A & PRÉ-B/CALLA+ & R & RCC(ET) & 43 \\
1617 & 54 & M & 2200 & B & PRÉ-B/CALLA+ & R & RCC(ET) & 42 \\
1622 & 58 & M & 11600 & B & PRÉ-B/CALLA+ & R & RCC(ET) & 42 \\
1658 & 39 & F & 76900 & A & PRÉ-B/CALLA+ & NR & RCC(ET) & 39 \\
1683 & 34 & F & 5600 & A & PRÉ-B/CALLA+ & L & TRANSF. & 37 \\
1692 & 117 & F & 12600 & A & PRÉ-B/CALLA+ & R & RCC(ET) & 37 \\
1693 & 47 & M & 51100 & A & PRÉ-B/CALLA+ & R & RCC(ET) & 37 \\
1699 & 51 & M & 2700 & B & PRÉ-B/CALLA+ & R & RCC(ET) & 37 \\
1704 & 52 & F & 64100 & A & PRÉ-B/CALLA+ & R & RCC(ET) & 36 \\
1711 & 160 & F & 9100 & A & PRÉ-B/CALLA+ & NR & Recidiva & 12 \\
1715 & 139 & F & 1300 & A & CÉL-T/CALLA- & R & TRANSF. & 35 \\
1730 & 65 & M & 83900 & A & CÉL-T/CALLA- & R & RCC(FT) & 35 \\
1741 & 186 & F & 2900 & A & PRÉ-B/CALLA+ & R & RCC(ET) & 34 \\
1766 & 82 & M & 2900 & A & PRÉ-B/CALLA+ & R & RCC(ET) & 34 \\
1919 & 51 & M & 5100 & A & PRÉ-B/CALLA+ & NR & RCC(ET) & 24 \\
2044 & 76 & F & 43900 & A & PRÉ-B/CALLA+ & NR & RCC(ET) & 22 \\
2090 & 26 & M & 33800 & B & PRÉ-B/CALLA+ & NR & ET & 19 \\
2101 & 37 & F & 6700 & B & PRÉ-B/CALLA+ & NR & ET & 19 \\
\hline
\end{tabular}

Abreviaturas: $\mathbf{A}=$ alto; $\mathbf{B}=$ baixo; $\mathbf{D R M}=$ doença residual mínima; $\mathbf{E T}=\mathrm{em}$ tratamento; $\mathbf{F T}=$ fora de tratamento; $\mathbf{F}=$ feminino; $\mathbf{G B}=$ glóbulos brancos (/dL); $\mathbf{L}=$ Lenta (maus respondedores); $\mathbf{m}=$ meses; $\mathbf{M}=$ masculino; $\mathbf{N R}=$ não realizado; $\mathbf{R}=$ Rápida (bons respondedores); $\mathbf{R C C}=$ remissão clínica completa; rec=recidiva; +=positivo; -=negativo.

Os critérios relativos à classificação dos pacientes quanto à resposta ao tratamento utilizados neste trabalho, foram baseados nos critérios estabelecidos pelo Grupo Brasileiro de Tratamento da Leucemia Infantil (GRUPO BRASILEIRO DE TRATAMENTO DA LEUCEMIA INFANTIL, 1993; 1999).

A Remissão Clínica Completa (RCC) foi definida como quantidade inferior a $5 \%$ de blastos leucêmicos na medula óssea, analisados por citologia 
convencional e ausência de sintomas ou sinais físicos atribuíveis à leucemia no vigésimo e oitavo dia da indução. A Sobrevida Livre de Eventos (SLE) é definida como o tempo decorrido desde o início do tratamento, até a ocorrência de falha indutória, da recaída, de morte por qualquer causa ou perda de seguimento (GRUPO BRASILEIRO DE TRATAMENTO DA LEUCEMIA INFANTIL 1999).

Além das amostras de medula óssea de pacientes portadores de LLA, foram analisadas 10 amostras de medula óssea sem doença hematológica do banco de medula óssea de pacientes não-oncológicos, aprovado pelo Comitê de Ética em Pesquisa (Proc. 9374/2003). 
4. MATERIAL E MÉTODOS 


\subsection{Coleta e Processamento das Amostras de Medula Óssea}

As amostras de medula óssea foram coletadas em tubos de vidro Vacutainer® contendo EDTA e processadas conforme procedimento de rotina do laboratório de Oncologia Pediátrica do HC/FMRP-USP. Após a coleta da amostra de medula óssea realizou-se a transferência para um tubo do tipo Falcon de $50 \mathrm{~mL}$ onde foi lavada com $25 \mathrm{~mL}$ de solução de cloreto de amônio $0,144 \mathrm{M}$ e bicarbonato de amônio 0,01 M. O conteúdo foi agitado lentamente por 3 minutos e centrifugado a $13200 \mathrm{rpm}$ por 10 minutos a $4^{\circ} \mathrm{C}$. Em seguida foi desprezada a fase aquosa e acrescentaram-se de 500 a $1000 \mu \mathrm{L}$ de PBS preparado conforme protocolo descrito no Anexo 3, dependendo do volume do material obtido. Posteriormente foi acrescentado TRIZOL LS Reagent ${ }^{\circledR}$ (Invitrogen, EUA) em uma quantidade correspondente a três vezes o volume de PBS aplicado (para cada $500 \mu \mathrm{L}$ de suspensão celular acrescentou-se $1500 \mu \mathrm{L}$ de TRIZOL LS Reagent $\left.{ }^{\circledR}\right)$. O material foi homogeneizando com pipeta até dissolução completa. Após este procedimento, foram adicionados $1000 \mu \mathrm{L}$ da solução em cada tubo eppendorf e o material foi armazenado no freezer $\mathrm{a}-80^{\circ} \mathrm{C}$. 


\subsection{Extração de RNA}

A extração do RNA foi realizada a partir do processamento da medula óssea descrito acima. Primeiramente foram acrescentados $200 \mu \mathrm{L}$ de clorofórmio para cada $1000 \mu \mathrm{L}$ de solução contendo TRIZOL LS Reagent ${ }^{\circledR}$. O material foi agitado lentamente por 15 segundos e centrifugado a $13.200 \mathrm{rpm}$ por 15 minutos a $4^{\circ} \mathrm{C}$. A fase aquosa superior foi coletada e transferida para novos tubos devidamente identificados. O RNA foi precipitado com $500 \mu \mathrm{L}$ de álcool isopropílico $100 \%$ mantido em repouso à $-20^{\circ} \mathrm{C}$ por pelo menos 12 horas.

Após esta etapa, a amostra foi centrifugada a $12000 \mathrm{rpm}$ por 20 minutos a $4^{\circ} \mathrm{C}$ desprezando-se em seguida o sobrenadante. Acrescentou-se $1.000 \mu \mathrm{L}$ de etanol $75 \%$ seguido novamente de centrifugação refrigerada a $4{ }^{\circ} \mathrm{C}$ por 5 minutos a $13.200 \mathrm{rpm}$. Desprezou-se a fase superior e o pellet foi dissolvido em água tratada

com dietilpirocarbonato (DEPC) por pelo menos 15 minutos (Anexo 3). Em seguida, esse material foi aliquotado, identificado e armazenado a $-80^{\circ} \mathrm{C}$. 


\subsection{Síntese de DNA complementar (cDNA)}

A síntse do cDNA foi realizada com a utilização do Kit para Transcrição Reversa da Applied Biosystems ${ }^{\circledR}$ (High Capacity cDNA Reverse Transcription Kit Applied Biosystems $\left.{ }^{\circledR}\right)$. Os procedimentos referentes à síntese do cDNA foram realizados de acordo com as recomendações do fabricante.

Para cada reação de transcrição reversa foram utilizados $2 \mu \mathrm{L}$ de RNA das amostras dos pacientes com LLA. Assim, para cada reação com $2 \mu \mathrm{L}$ de RNA, utilizou-se $2,5 \mu \mathrm{L}$ de buffer, $1 \mu \mathrm{L}$ de dNTP, $2,5 \mu \mathrm{L}$ de Random Primers, $1,25 \mu \mathrm{L}$ de multiscribe, $0,63 \mu \mathrm{L}$ de RNAse OUT e $15,12 \mu \mathrm{L}$ de água tratada com DEPC. A quantidade citada de cada reagente foi multiplicada pelo número de amostras de RNA para a confecção de um "Mix". Posteriormente, $23 \mu \mathrm{L}$ desse Mix foi adicionado a cada tubo eppendorf. Em seguida foram adicionados $2 \mu \mathrm{L}$ de RNA de cada amostra nos frascos devidamente identificados.

Finalmente os tubos eppendorf foram submetidos ao termociclador onde foram realizados os ciclos de $\mathrm{PCR}$ a $25^{\circ} \mathrm{C}$ por 10 minutos e $37^{\circ} \mathrm{C}$ por 120 minutos. As amostras de cDNA foram armazenadas em um freezer a uma temperatura de $20^{\circ} \mathrm{C}$. 


\subsection{Controle endógeno}

O gene GUS $\beta$ codifica a proteína beta-glucuronidase que é expressa em todas as células nucleadas. Este gene está localizado no cromossomo 7 e possui níveis de expressão constantes em diferentes tipos celulares. Recentemente, o Europe Against Cancer Program (EACP) realizou uma análise detalhada de vários genes candidatos a controles endógenos em um estudo de leucemia, sendo o gene GUS $\beta$ considerado apropriado para o estudo por apresentar baixa variabilidade de expressão e não apresentar pseudogenes. Além disso, o $G U S \beta$ não apresenta expressão dependente do ciclo celular (BEILLARD et al., 2003). Devido a estas características, o gene GUS $\beta$ foi utilizado como controle endógeno neste trabalho para a realização da normalização dos níveis de expressão dos genes estudados. 


\subsection{Oligonucleotídeos}

As seqüências dos oligonucleotídeos (primer e sonda) para os 4 genes das HDACs de classe I e para o gene GUS $\beta$ foram obtidos através do programa Primer Express (Applied Biosystems) solicitados in silico no site: https://products.appliedbiosystems.com. As seqüências dos primers utilizados são apresentadas na Tabela 4 .

Tabela 4 - Seqüência dos primers para a PCR em tempo real dos genes GUS $\beta$, HDAC1, HDAC2, HDAC3 e HDAC8.

\begin{tabular}{cr}
\hline Primer & Seqüência \\
\hline GUS $\beta$ sense & $\mathbf{5}^{\prime}$ GAAAATATGTGGTTGGAGAGCTCATT 3' \\
GUS $\beta$ antisense & $\mathbf{5}^{\prime}$ CCGAGTGAAGATCCCCTTTTTA 3' \\
HDACl sense & $\mathbf{5}^{\prime}$ CCTGGATACGGAGATCCCTA \\
HDAC 1 antisense & $\mathbf{5}^{\prime}$ CCGCAAGAACTCTTCCAACT \\
$H D A C 2$ sense & $\mathbf{5}^{\prime}$ CCTTGATTGTGAGATTCCCA \\
$H D A C 2$ antisense & $\mathbf{5}^{\prime}$ AGGAGGTCGAAGAAATGTGG \\
$H D A C 3$ sense & $\mathbf{5}^{\prime}$ CTCTCTGGGCTGTGATCGAT \\
$H D A C 3$ antisense & $\mathbf{5}^{\prime}$ CAATCTTTGAAAACCTGAAGATG \\
$H D A C 8$ sense & $\mathbf{5}^{\prime}$ AGGTGACGTGTCTGATGTTG \\
$H D A C 8$ antisense & $\mathbf{5}^{\prime}$ CTCTGAGATCCCAGATCATG
\end{tabular}




\subsection{PCR em tempo real}

A quantificação da expressão gênica foi realizada a partir da análise da técnica de reação em cadeia da polimerase em tempo real (RQ-PCR) realizadas no aparelho 7500 Real-Time PCR System ${ }^{\circledR}$ (Applied Biosystems) disponível no Laboratório de Puericultura e Pediatria do HC/FMRP-USP. As reações foram preparadas utilizando se TaqMan ${ }^{\circledR}$ Universal PCR Marter Mix (Applied Biosystems) otimizado para reações com sonda TaqMan contendo AmpliTaq Gold DNA polimerase, dNTPs, dUTP, e tampão otimizado.

O preparo e armazenamento do material foram realizados de acordo com as instruções do fabricante, excetuando o volume final de cada reação otimizado em $12 \mu \mathrm{L}$. Para cada reação foram utilizados $6,0 \mu \mathrm{L}$ de TaqMan PCR Master Mix, 0,6 $\mu \mathrm{L}$ de sonda TaqMan e 5,4 $\mu \mathrm{L}$ de cDNA (diluído 1:20). Após esta etapa, as reações foram centrifugadas por 1 minuto a $13.000 \mathrm{rpm}$. Todas as etapas do procedimento descrito foram realizadas com as amostras imersas em gelo com pouca exposição à luz.

Na preparação das reações foram utilizadas placas de polipropileno para 96 reações (ultraAmp 96-well Semi-Skirt PCR plates, Sorenson BioScience, EUA) cobertas com adesivos para microplacas ópticas resistentes a álcool e altas temperaturas (Adhesive PCR film, ABgene). 
A reação da PCR em tempo real foi padronizada em estudo piloto para definição das melhores condições de desnaturação, anelamento e amplificação. As condições finais para a reação de PCR foram as seguintes: pré-aquecimento a $50^{\circ} \mathrm{C}$ por 2 minutos, ativação da polimerase a $95^{\circ} \mathrm{C}$ por 10 minutos e 40 ciclos de desnaturação $\left(15\right.$ segundos a $\left.95^{\circ} \mathrm{C}\right)$ e anelamento e extensão $\left(60\right.$ segundos a $\left.60^{\circ} \mathrm{C}\right)$.

Cada amostra foi avaliada em duplicata e foram consideradas para análise somente as amostras cuja diferença de amplificação não excedeu um ciclo e meio (VAN DER VELDEN et al., 2003). As duplicatas das amostras que apresentaram diferenças maiores que um ciclo e meio, mesmo após repetição do experimento, foram desconsideradas. Em todas as placas foram realizados controles negativos das reações para todos os genes estudados (HDAC1, HDAC2, HDAC2, HDAC8 e GUS $\beta$ ) sendo que nestas reações adicionou-se $5,4 \mu \mathrm{L}$ de água ao invés de cDNA. Assim, as reações que mostram amplificação para qualquer um dos controles negativos foram desconsideradas.

O valor de 0,1 do threshold foi determinado manualmente na fase exponencial da reação de RQ-PCR para todos os genes estudados em todas as placas. A partir do threshold estabelecido, os valores de Cicle thresold $\left(\mathrm{C}_{\mathrm{T}}\right)$ foram fornecidos pelo software do aparelho 7500 Real-Time PCR System ${ }^{\circledR}$. 
Uma amostra contendo cDNA de uma medula óssea sem doença hematológica (Mo 10) foi utilizada como calibrador em todas as reações para os todos os genes estudados. Essa amostra foi utilizada apenas como um parâmetro comparativo da expressão dos genes estudados e não como referência normal, pois sabe se que a medula óssea sem doença hematológica não reproduz com exatidão a contraparte normal da população celular de precursores hematopoéticos presentes em medula óssea leucêmica (REGO et al., 2001).

Os cálculos de normalização das amostras foram realizados pelo software do aparelho 7500 Real-Time PCR System ${ }^{\circledR}$, sendo que a média dos valores da expressão relativa de cada duplicata foram normalizados pelos valores da expressão do housekeeper (GUS) para obtenção do valor do $\Delta \mathrm{C}_{\mathrm{T}}\left[\Delta \mathrm{C}_{\mathrm{T}}=\mathrm{C}_{\mathrm{T}}(\mathrm{HDAC})-\mathrm{C}_{\mathrm{T}}\right.$ (GUS)]. Os resultados $(\Delta \mathrm{Ct})$ foram utilizados para o cálculo das diferenças dos valores da expressão entre cada amostra e o calibrador obtendo se os valores do $\Delta \Delta \mathrm{C}_{\mathrm{T}}$. O método $2^{-\Delta \Delta \mathrm{CT}}$ recomendado por Livak e Schmittgen (2001) foi utilizado para o cálculo da expressão relativa dos genes determinados pelos experimentos de RQ-PCR. 


\subsection{Análise Estatística}

Os resultados foram analisados com o auxílio do programa de análise estatística SPSS 10.0 for Windows. A assessoria estatística foi realizada pelo Professor Dr.Carlos Alberto Scrideli.

Utilizou-se o teste de significância estatística de Fisher e o teste nãoparamétrico de Mann-Whitney para verificar a correlação entre os níveis de expressão dos genes de Classe I das HDACs e as variáveis clínicas e do prognóstico dos pacientes portadores de LLA. Para comparar os níveis de expressão dos genes de Classe I das HDACs nas amostras de pacientes com LLA e nas amostras de medula óssea de doadores sem doença hematológica utilizou-se o teste de Mann-Whitney.

As curvas da sobrevida livre de eventos foram geradas pelo método de Kaplan-Meier e analisadas utilizando-se o teste de Log-Rank (Mantel-Cox).

Para a análise da correlação linear entre os genes de Classe I das HDACs foi utilizado o teste de Spearman. 
5. RESULTADOS 


\section{RESULTADOS}

Neste estudo foi avaliada a expressão dos genes das Histonas Desacetilases de Classe I (HDAC1, HDAC2, HDAC3 e HDAC8) em 46 amostras consecutivas de medula óssea de crianças e adolescentes portadores de LLA coletadas no diagnóstico e 10 de amostras de doadores de medula óssea sem doença hematológica. Os valores de expressão relativa dos genes nas amostras foram normalizados pelo valor de expressão encontrado para o controle endógeno (GUS $\beta$ ) e divididos pelo valor do calibrador normalizado. A Tabela 5 mostra os valores encontrados da expressão relativa dos genes estudados nas amostras dos pacientes.

Tabela 5 - Valores da expressão relativa dos genes de classe I das HDACs em amostras de medula óssea de pacientes portadores de LLA.

\begin{tabular}{ccccc}
\hline Paciente & HDAC1 & HDAC2 & HDAC3 & HDAC8 \\
\hline 628 & 0.787 & 0.305 & 0.164 & 1.532 \\
707 & 0.671 & 0.155 & 1.987 & 24.892 \\
722 & 1.693 & 0.635 & 1.344 & 7.955 \\
732 & 5.552 & 2.257 & 6.859 & 34.331 \\
741 & 1.571 & 0.585 & 2.024 & 0 \\
874 & 2.351 & 0.906 & 0.802 & 0.578 \\
931 & 3.412 & 1.293 & 1.412 & 1.235 \\
972 & 0.223 & 1.228 & 2.344 & 3.807 \\
1055 & 0.904 & 0.517 & 0.467 & 0.34 \\
1066 & 1.847 & 2.076 & 0.296 & 1.537 \\
1069 & 1.455 & 3.981 & 0.396 & 0 \\
1111 & 1.224 & 0.39 & 1.092 & 2.226 \\
1128 & 7.687 & 0.462 & 0.996 & 0.547 \\
1130 & 2.702 & 0.343 & 1.052 & 0.498 \\
1179 & 5.524 & 2.503 & 1.377 & 1.079
\end{tabular}


Continuação

\begin{tabular}{|c|c|c|c|c|}
\hline Paciente & HDAC1 & HDAC2 & HDAC3 & HDAC8 \\
\hline 1200 & 2.554 & 1.265 & 0.972 & 0.974 \\
\hline 1259 & 1.653 & 1.933 & 0.8 & 2.265 \\
\hline 1292 & 2.141 & 4.781 & 0.531 & 1.788 \\
\hline 1325 & 1.579 & 3.293 & 1.351 & 1.46 \\
\hline 1328 & 2.8 & 2.483 & 0.671 & 1.598 \\
\hline 1385 & 0.325 & 0.383 & 0.403 & 0.978 \\
\hline 1390 & 1.88 & 0.961 & 0.556 & 0.994 \\
\hline 1418 & 2.793 & 1.344 & 0.805 & 1.018 \\
\hline 1434 & 0.036 & 0.233 & 0.075 & 0.281 \\
\hline 1498 & 4.064 & 3.685 & 1 & 4.301 \\
\hline 1521 & 2.998 & 2.945 & 1.386 & 1.495 \\
\hline 1535 & 2.187 & 3.543 & 1.042 & 0 \\
\hline 1572 & 1.022 & 2.685 & 1.163 & 0.533 \\
\hline 1574 & 2.118 & 8.542 & 1.279 & 5.279 \\
\hline 1617 & 9.514 & 7.929 & 1.617 & 1.274 \\
\hline 1622 & 1.218 & 2.203 & 0.777 & 0.848 \\
\hline 1658 & 0.504 & 0.703 & 0.08 & 0.189 \\
\hline 1683 & 1.875 & 2.095 & 2.628 & 2.906 \\
\hline 1692 & 1.884 & 7.689 & 5.187 & 3.748 \\
\hline 1693 & 0.796 & 0.783 & 0.434 & 0.47 \\
\hline 1699 & 0.792 & 0.259 & 0.332 & 2.145 \\
\hline 1704 & 1.767 & 0.925 & 0.243 & 0.48 \\
\hline 1711 & 13.711 & 7.209 & 3.424 & 0.871 \\
\hline 1715 & 1.981 & 0.835 & 0.361 & 0.283 \\
\hline 1730 & 51.876 & 16.28 & 9.058 & 6.471 \\
\hline 1741 & 2.935 & 0.592 & 0.897 & 0.446 \\
\hline 1766 & 4.853 & 4.681 & 2.848 & 3.391 \\
\hline 1919 & 2.171 & 3.6 & 2.387 & 3.25 \\
\hline 2044 & 2.642 & 2.142 & 0.436 & 0.596 \\
\hline 2090 & 3.141 & 2.134 & 0.258 & 2.97 \\
\hline 2101 & 0.541 & 1.816 & 0.762 & 2.085 \\
\hline
\end{tabular}

Os valores da expressão relativa variaram entre as amostras dos pacientes portadores de LLA, para a HDAC1 (mediana $=2,0495)$ de 0,036 a 51,876, para a HDAC2 $($ mediana $=1,8745)$ de 0,155 a 16,28, para a HDAC3 $($ mediana $=0,984)$ de 0,075 a 9,058; e para a HDAC8 (mediana $=1,2545$ ) a expressão variou de 0 a 34,331 . 
De acordo com os valores da expressão dos genes estudados, os pacientes foram divididos em dois grupos. No primeiro, foram incluídos os pacientes em que os valores da expressão relativa dos genes foram menores ou iguais à mediana, e no segundo foram incluídos os pacientes que apresentaram valores maiores que a mediana. Os valores da expressão dos genes foram correlacionados com as características clínicas e do prognóstico dos pacientes com LLA descritas a seguir:

$\checkmark$ Idade: de 12 a 108 meses $(\mathrm{n}=31)$ versus $<$ que 12 meses e $>$ que 108 meses $(\mathrm{n}=15)$

$\checkmark$ Grupo de risco: baixo risco $(\mathrm{n}=16)$ versus alto risco $(\mathrm{n}=30)$.

$\checkmark$ Contagem de GB ao diagnóstico: $<50.000 / \mu 1(\mathrm{n}=32)$ versus $>50.000 / \mu 1(\mathrm{n}=14)$

$\checkmark$ Imunofenótipo: LLA CALLA $+(\mathrm{n}=36)$ versus LLA CALLA $-(\mathrm{n}=10)$.

$\checkmark$ Resposta ao Tratamento: bons respondedores $(\mathrm{n}=29)$ versus maus respondedores $(n=7)$.

$\checkmark$ Doença residual mínima no d14: ausência de DRM no d14 $(\mathrm{n}=20)$ versus presença de DRM no d14 ( $\mathrm{n}=10)$.

$\checkmark$ Doença residual mínima no d28: ausência de DRM no d28 (n=31) versus presença de DRM no d28 ( $\mathrm{n}=10)$.

$\checkmark$ Sobrevida livre de eventos em 5 anos: remissão clínica completa $(\mathrm{n}=32)$ versus recaída ou óbito $(\mathrm{n}=10)$.

$\checkmark$ Gênero: Feminino ( $\mathrm{n}=23$ ) versus Masculino ( $\mathrm{n}=23)$. 
As características clínicas e do prognóstico dos pacientes portadores de LLA descritas foram correlacionadas com a expressão relativa dos genes de Classe I das HDACs utilizando-se o teste de significância estatística de Fisher (Tabela 6).

Tabela 6 - Valores de "p" obtidos através do teste de Fisher relativos à expressão dos genes de Classe I das HDACs em amostras de medula óssea dos pacientes portadores de LLA.

\begin{tabular}{ccccc}
\hline Fisher test & HDAC1 & HDAC2 & HDAC3 & HDAC8 \\
\hline Idade & 0,104 & 0,1047 & 0,500 & 0,265 \\
GB & 0,625 & 0,375 & 0,168 & 0,168 \\
Risco & 0,177 & $\mathbf{0 , 0 6 0}$ & 0,621 & 0,621 \\
Imunofenótipo & 0,142 & 0,361 & 0,361 & 0,142 \\
Resposta & $\mathbf{0 , 0 6 1}$ & 0,500 & 0,369 & 0,500 \\
DRMd14 & 0,548 & 0,344 & 0,450 & 0,450 \\
DRMd28 & 0,607 & 0,393 & 0,537 & 0,326 \\
SLE & 0,500 & $\mathbf{0 , 0 8 1}$ & 0,570 & 0,244 \\
Gênero & 0,119 & $\mathbf{0 , 0 3 8}$ & 0,119 & 0,119 \\
\hline
\end{tabular}

Abreviaturas: DRMd14: Presença de Doença Residual Mínima no $14^{\circ}$ dia após o início do tratamento; DRMd28: Presença de Doença Residual Mínima no $28^{\circ}$ dia após o início do tratamento; GB: Contagem Inicial de Glóbulos Brancos; SLE: Sobrevida Livre de Eventos em 5 anos. Os valores próximos do nível de significância adotado $(\mathrm{p} \leq 0,05)$ estão marcados em negrito. 
Neste teste, as HDACs 1,3 e 8 não mostraram nenhuma correlação estatisticamente significativa com as características clínicas e laboratoriais dos pacientes portadores de LLA analisadas neste estudo, adotando se como nível de significância o valor de $\mathrm{p} \leq 0,05$. Entretanto, o teste de Fisher revelou uma expressão aumentada do gene $H D A C 2$ em pacientes do gênero masculino $(\mathrm{n}=23)$ em relação aos pacientes do gênero feminino $(n=23)$ com valor de $p=0,038$ como pode ser observado na Tabela 6.

Também foi realizada a análise da correlação entre a expressão dos genes de Classe I das HDACs e as características clínicas e do prognóstico dos pacientes portadores de LLA utilizando-se o teste não-paramétrico de Mann-Whitney. Nesta análise foi observada uma expressão relativa maior do gene $\operatorname{HDACl}(\mathrm{p}=0,036)$ nas amostras pertencentes aos pacientes do grupo de bons respondedores ao tratamento $(n=29)$ comparando-se com o grupo dos maus respondedores $(n=7)$ como é mostrado na Tabela 7. 
Tabela 7 - Valores de "p" obtidos através do teste de Mann-Whitney relativos à expressão dos genes de Classe I das HDACs nas amostras de medula óssea dos pacientes portadores de LLA.

\begin{tabular}{ccccc}
\hline Mann-Whitney & HDAC1 & HDAC2 & HDAC3 & HDAC8 \\
\hline Idade & 0,114 & 0,125 & 0,631 & 0,178 \\
GB & 0,445 & 0,924 & 0,110 & 0,305 \\
Risco & 0,333 & $\mathbf{0 , 0 6 2}$ & 0,818 & 0,982 \\
Imunofenótipo & 0,378 & 0,906 & 0,609 & 0,364 \\
Resposta & $\mathbf{0 , 0 3 6}$ & 0,696 & 0,345 & 0,667 \\
DRMd14 & 0,448 & $\mathbf{0 , 0 7 4}$ & 0,650 & 0,530 \\
DRMd28 & 0,540 & 0,870 & 0,731 & 0,345 \\
SLE & 0,689 & 0,259 & 0,248 & 0,308 \\
Gênero & 0,060 & $\mathbf{0 , 0 5 2}$ & 0,231 & 0,170 \\
\hline
\end{tabular}

Abreviaturas: DRMd14: Presença de Doença Residual Mínima no $14^{\circ}$ dia após o início do tratamento; DRMd28: Presença de Doença Residual Mínima no $28^{\circ}$ dia após o início do tratamento; GB: Contagem Inicial de Glóbulos Brancos; SLE: Sobrevida Livre de Eventos em 5 anos. Os valores próximos do nível de significância adotado $(\mathrm{p} \leq 0,05)$ estão marcados em negrito.

A expressão relativa dos genes $H D A C 3$ e $H D A C 8$, não mostraram nenhuma correlação estatisticamente significativa com as características clínicas e do prognóstico dos pacientes com LLA avaliadas neste estudo. 
Outro teste realizado neste estudo foi a comparação dos valores obtidos para a expressão relativa dos genes de classe I das HDACs nas 46 amostras de medula óssea de pacientes com LLA com as 10 amostras de doadores sem doença hematológica. Neste teste, obteve-se uma diferença estatisticamente significativa para a expressão de 3 dos 4 genes estudados. Os genes $H D A C 2(\mathrm{p}=0,007)$, $H D A C 3(\mathrm{p}=0,014)$ e HDAC8 $(\mathrm{p}=0,002)$ foram mais expressos nas amostras de LLA comparando-se com as amostras de medula óssea sem doença hematológica, enquanto que para o gene $H D A C 1$, não foram observadas diferenças significativas nesta análise. Os resultados desse teste estão representados na Figura 1. 

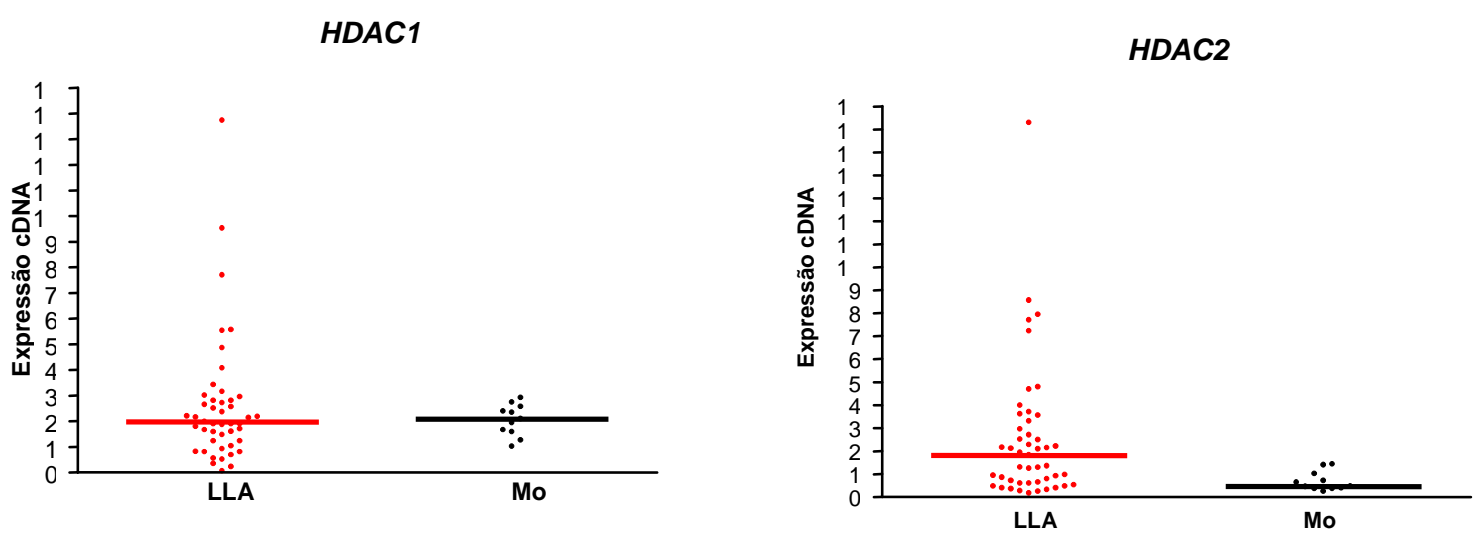

HDAC3

HDAC8
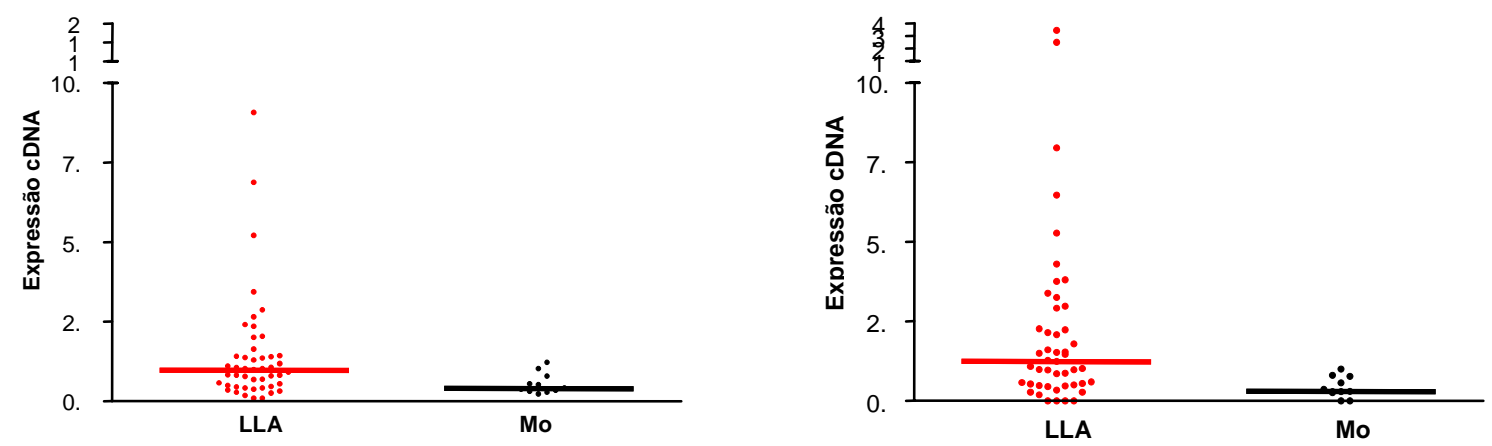

Figura 1. Comparação da expressão dos genes de classe I das HDACs em 46 amostras de pacientes com LLA e 10 de amostras medula óssea de doadores sem doença hematológica.

Abreviaturas: LLA: Amostras de Medula Óssea de crianças e adolescentes com LLA ( $\mathrm{n}=46)$; Mo: Amostras de medula óssea de doadores sem doença hematológica $(\mathrm{n}=10)$. 
Para a análise da sobrevida livre de eventos, utilizou-se as curvas de Kaplan-Meier e o teste de Log-Rank. As Figuras 2, 3, 4 e 5 mostram essas curvas e os valores de "p"obtidos através do teste de Log-Rank para cada gene de classe I das HDACs.

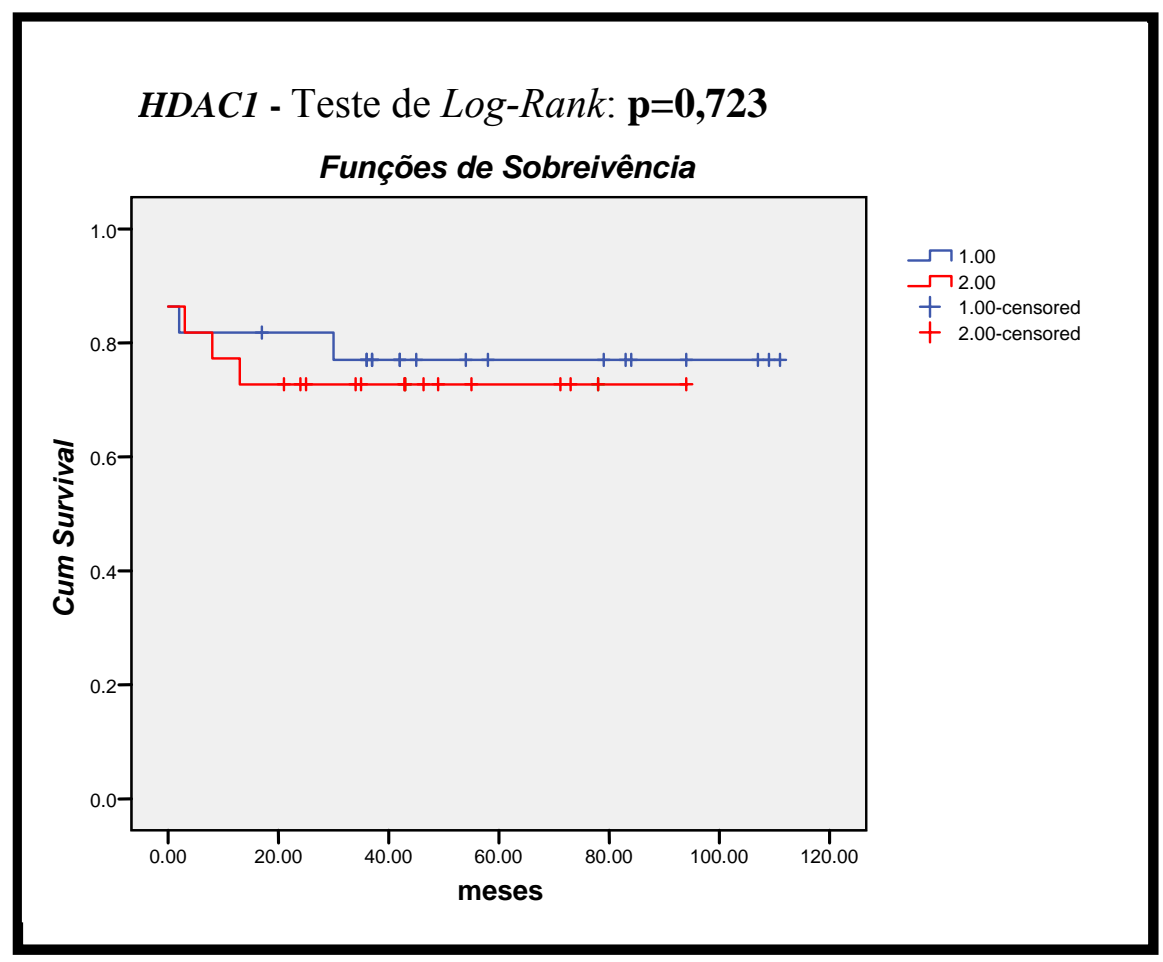

Figura 2: Curvas de Kaplan-Meier e resultado do teste de Log-Rank obtido através da análise da expressão relativa do gene $H D A C 1$ e Sobrevida Livre de Eventos dos pacientes portadores LLA.

Abreviaturas: 1,00 $=$ Grupo de pacientes com expressão menor que a mediana; $\mathbf{2 , 0 0}=$ Grupo de pacientes com expressão maior que a mediana. 


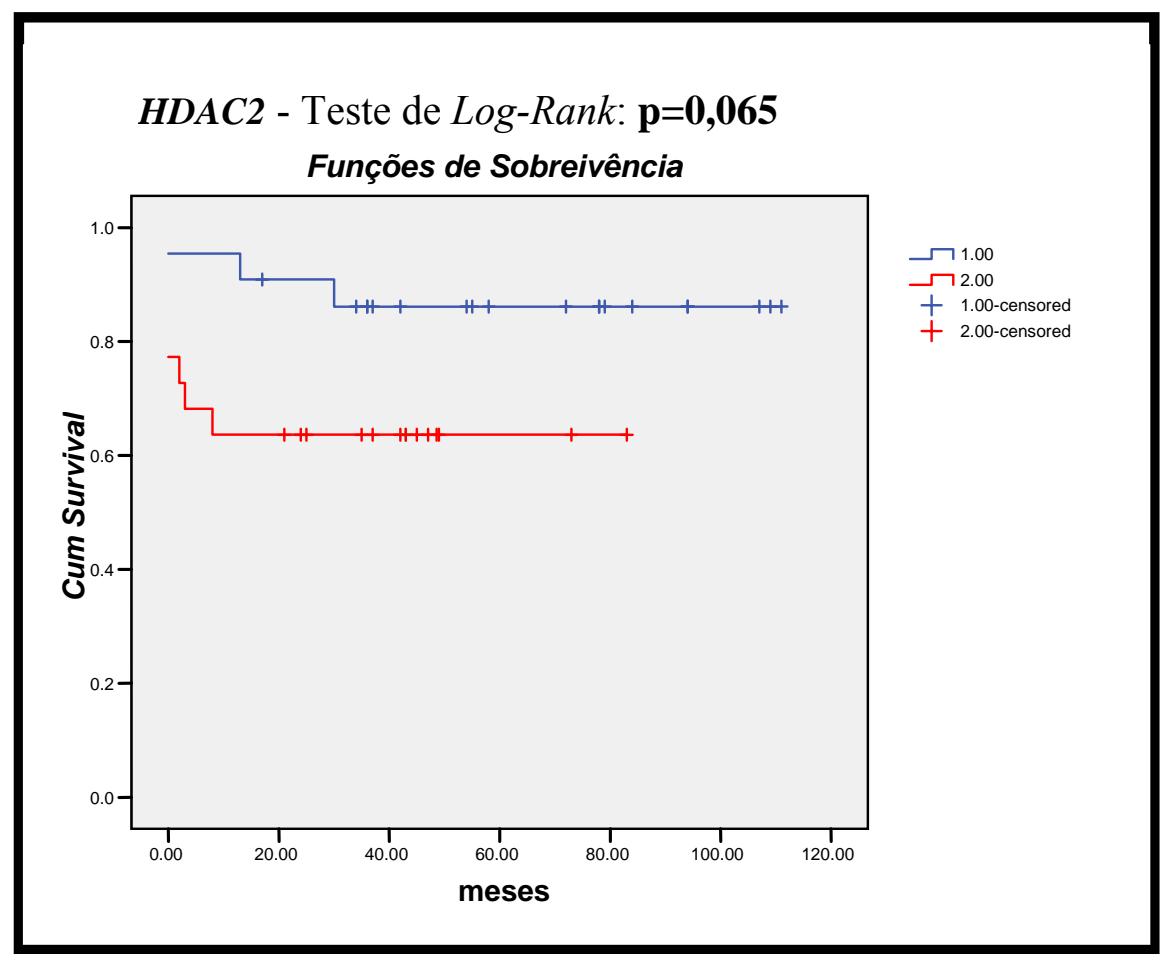

Figura 3: Curvas de Kaplan-Meier e resultado do teste de Log-Rank obtido através da análise da expressão relativa do gene $H D A C 2$ e sobrevida livre de eventos dos pacientes portadores LLA.

Abreviaturas: 1,00=Grupo de pacientes com expressão menor que a mediana; $\mathbf{2 , 0 0}=$ Grupo de pacientes com expressão maior que a mediana. 


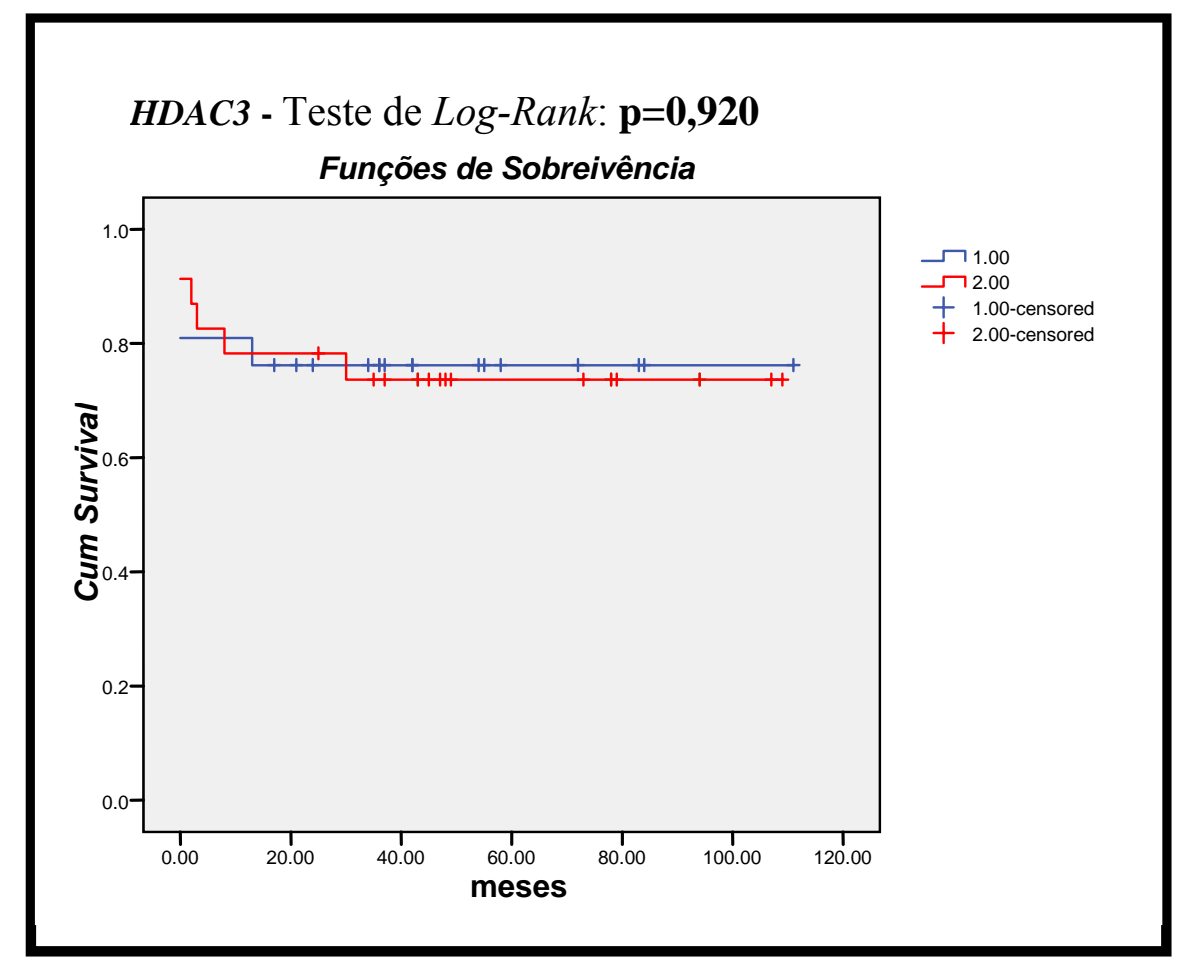

Figura 4: Curvas de Kaplan-Meier e resultado do teste de Log-Rank obtido através da análise da expressão relativa do gene $H D A C 3$ e Sobrevida Livre de Eventos dos pacientes portadores LLA.

Abreviaturas: 1,00 $=$ Grupo de pacientes com expressão menor que a mediana; $\mathbf{2 , 0 0}=$ Grupo de pacientes com expressão maior que a mediana. 


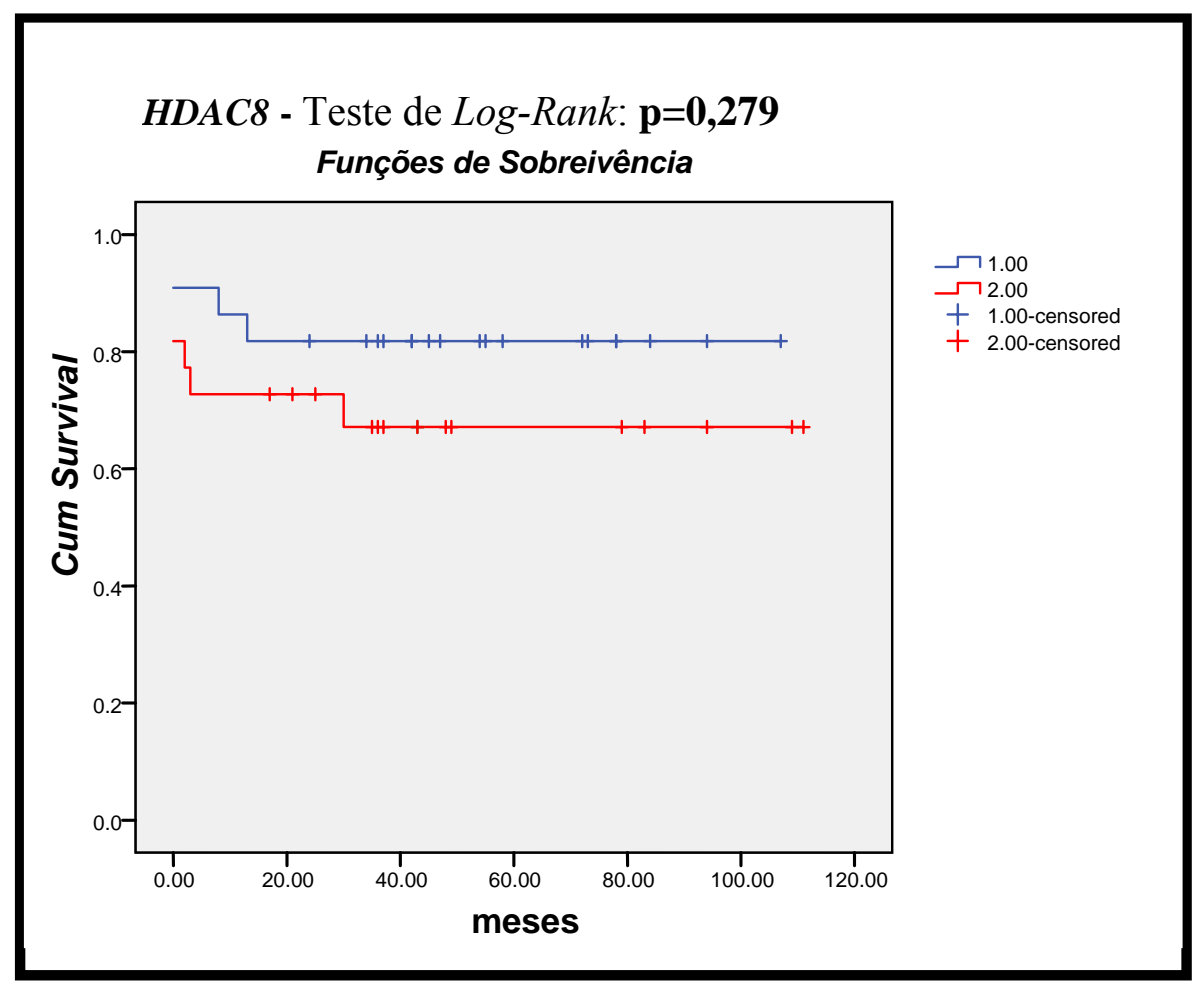

Figura 5: Curvas de Kaplan-Meier e resultado do teste de Log-Rank obtido através da análise da expressão relativa do gene $H D A C 8$ e sobrevida livre de eventos dos pacientes portadores LLA.

Abreviaturas: $1,00=$ Grupo de pacientes com expressão menor que a mediana; $\mathbf{2 , 0 0}=$ Grupo de pacientes com expressão maior que a mediana. 
Como pode ser observado na figura 3, o gene $H D A C 2$ foi mais expresso no grupo de pacientes com sobrevida menor, entretanto, o valore obtido através do teste de Log-Rank não foi estatisticamente significativo $(\mathrm{p}=0,065)$.

O teste de Spearman foi utilizado para o cálculo da relação linear entre os genes estudados. Esse teste mostrou uma correlação entre a expressão dos genes HDAC1 e HDAC2 (p=0,000); HDACs1 e HDAC3 ( $(\mathrm{p}=0,002) . H D A C 2$ e HDAC8 $(\mathrm{p}=0,044) ; H D A C 3$ e HDAC8 $(\mathrm{p}=0,001)$. Nesta análise só não houve correlação entre os genes $H D A C 1$ e $H D A C 8$. Os resultados desse teste são mostrados na Figura 6.

Figura 6. Teste de Spearman: correlação linear entre os genes estudados.

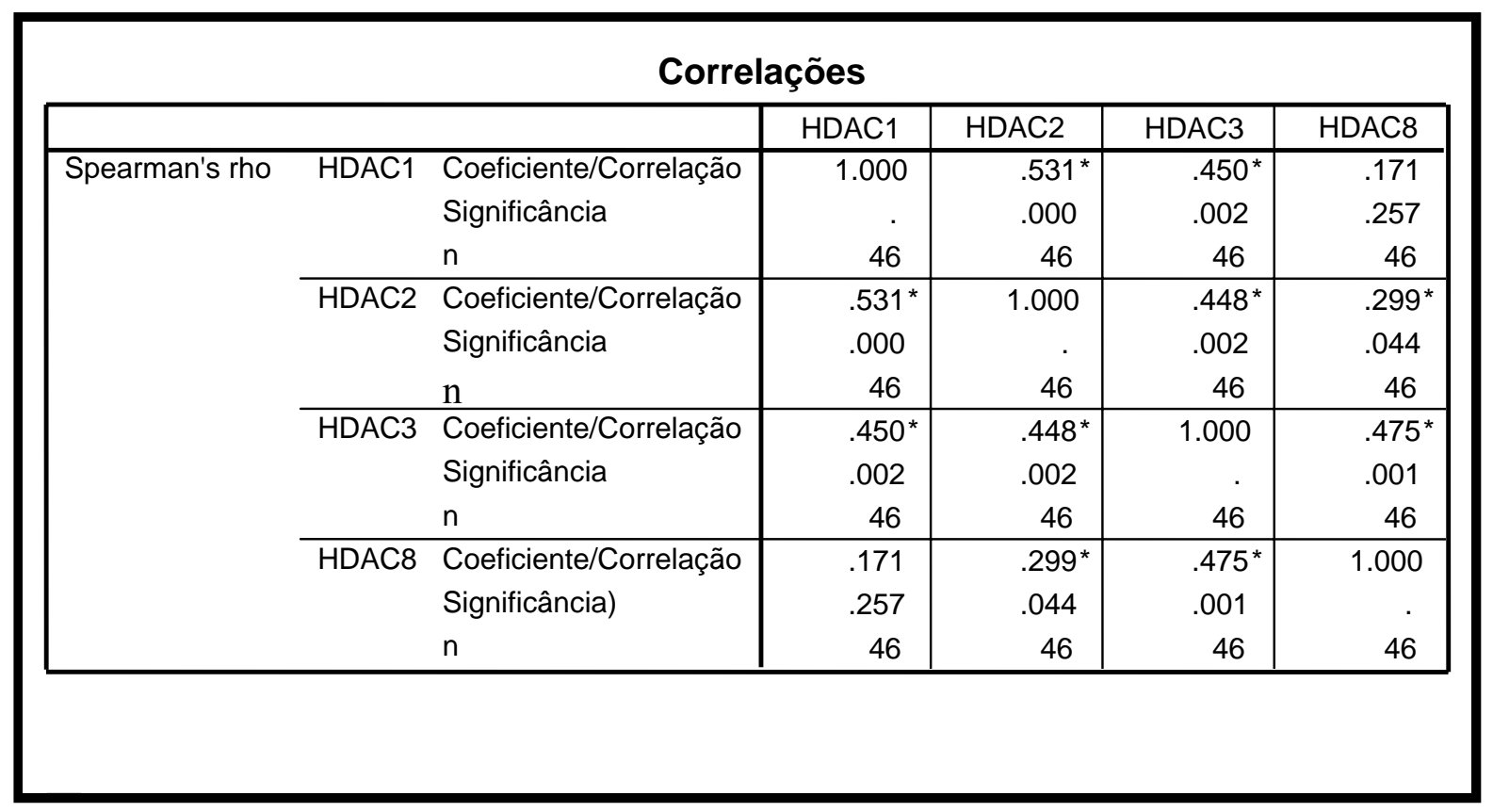

Abreviaturas: $\mathbf{n}=$ Número de amostras analisadas de pacientes com LLA; * = Correlação significativa para $\mathrm{p}<0,05$. 
Os resultados deste teste mostram que há uma correlação entre a expressão dos genes de classe I das HDACs. Alguns estudos afirmam que de fato, com exceção da HDAC8, todas as outras HDACs realizam associações a complexos multiproteicos co-repressores da atividade transcricional (incluindo outras HDACs) para se tornarem funcionais (GALLINARI 2007). 


\section{DISCUSSÃO}




\section{DISCUSSÃO}

Além das alterações genéticas, tem-se tornado cada vez mais evidente que o desenvolvimento e a progressão do câncer dependem também de alterações nos mecanismos epigenéticos relacionados ao padrão de expressão gênica, diferenciação e memória celular (BAYLIN; OHM, 2006; LU et al., 2006; ROPERO; ESTELLER, 2007). A influência dos mecanismos epigenéticos no desenvolvimento do câncer reflete a importância da sinalização da matriz extracelular e das interações entre as células neoplásicas com as células estromais.

Desta forma, o microambiente celular pode provocar modificações epigenéticas com o potencial de promover ou prevenir o desenvolvimento de neoplasias (LUND; VAN LOHUZEN 2004; ESTELLER; ALMOUZNI, 2005; HOLLIDAY, 2006).

Além disso, diferente das alterações genéticas que são estáveis e raramente reversíveis, as modificações epigenéticas frequentemente podem ser revertidas e este fato oferece novas oportunidades para a intervenção terapêutica e controle do câncer (ESTELLER, 2006; HOLLIDAY, 2006; LAIRD, 2005; LEHMANN; BRAKENSIEK; KREIPE; 2004; TING; MCGARVEY; BAYLIN, 2006). 
Esses mecanismos epigenéticos incluem principalmente a metilação do DNA e as modificações nas histonas. Muitos estudos revelaram padrões aberrantes de metilação do DNA associado a diversas neoplasias. A hipometilação global pode afetar a expressão de oncogenes e gerar instabilidade genômica enquanto que a hipermetilação de regiões promotoras de genes supressores tumorais pode provocar silenciamento desses genes e descontrole no ciclo celular (JONES; BAYLIN, 2002; LEHMANN; BRAKENSIEK; KREIPE; 2004; LUND; VAN LOHUZEN 2004). No câncer também são comuns alterações na atividade de enzimas que participam de processos que resultam em modificações na estrutura da cromatina. Essas modificações ocorrem particularmente nos resíduos de aminoácidos das proteínas histonas (HILDMAN; RIESTER; SCHWIENHORST, 2007; TING; MCGARVEY; BAYLIN, 2006).

As modificações nas proteínas histonas também têm sido associadas com desregulação na expressão de muitos genes que desempenham papéis importantes no ciclo celular. Além disso, estudos recentes sugerem que as células de tecidos neoplásicos apresentam diferenças em relação às modificações específicas nas histonas, e que essa heterogeneidade epigenética pode apresentar um valor prognóstico importante (KURDISTANI, 2007).

Selingston et al. (2005) realizaram um estudo focando as modificações nas histonas e o valor prognóstico em câncer de próstata. Nesse estudo foi 
demonstrado que o padrão de modificações nas histonas mostrou dois grupos de risco significativamente diferentes em relação à recorrência do tumor e revelou ser um fator independente das outras características clínicas e patológicas.

Entre os diversos mecanismos epigenéticos que provocam modificações nas histonas, a acetilação é o melhor caracterizado. Esse processo é considerado um evento essencial na modulação da expressão gênica e o descontrole nesse mecanismo mediado pela atividade das HATS e HDACs, resulta em alterações no padrão normal de expressão dos genes e no desequilíbrio da homeostase celular (MAHLKNECH; OTTMANN; HOELZER, 2000; RUIJTER et al., 2003; LU et al., 2006; GALLINARI et al., 2007).

Atualmente sabe-se que alterações no processo de acetilação das histonas e de proteínas não histonas é uma característica comum do câncer. Além disso, anormalidades envolvendo as HDACs como mutações, expressão alterada e recrutamento aberrante, tem sido observado em diversas neoplasias (MINUCCI; PELICCI, 2006; ROPERO; ESTELLER, 2007).

Apesar de estarem envolvidas em muitos processos biológicos (GALLINARI et al., 2007), as HDACs são consideradas reguladores críticos relacionados à proliferação celular, diferenciação e programas de apoptose (HILDMAN; RIESTER; SCHWIENHORST, 2007). Mesmo antes do conhecimento de suas propriedades inibitórias das HDACs já havia relatos a 
respeito dos efeitos benéficos dos iHDAC em tumores pediátricos (DRIEVER et al., 1999). Posteriormente, vários estudos demonstraram que iHDACs como o TSA (thricostatin A), ATRA (All-trans retinoic acid), SAHA (suberoylanilide hydroxamic acid) e VPA (Valproic acid) induzem parada do ciclo celular, diferenciação e apoptose em diversos tipos de neoplasias (PEART et al., 2003; WILSON et al., 2006; BI; JIANG, 2006; MINICCI; PELICCI, 2006; MARKS, 2007) incluindo LLA (ROMANSKI et al., 2004)

Esses estudos envolvendo iHDACs são extremamente importantes para a compreensão do funcionamento das HDACs. Sabe-se que muitos iHDACs são específicos para determinadas HDACs e que seus efeitos dependem do tempo de exposição e da linhagem celular a qual foram submetidos. Assim, tem sido sugerido que o bloqueio da atividade de uma determinada HDAC pode resultar em diferentes efeitos em relação à expressão gênica em diferentes linhagens celulares (GLASER et al., 2003; BI; JIANG, 2006). Possivelmente, as HDACs atuam por vias metabólicas diferentes dependendo do tipo de tecido ou do estágio de diferenciação celular.

Acredita-se que o descontrole provocado pelo desequilíbrio na atividade das HATs e HDACs possa provocar alterações na expressão gênica tanto de maneira não-específica quanto de maneira específica. 
Por um lado, a redução na atividade das HDACs e aumento da atividade das HATs, podem resultar na ativação de genes previamente silenciados ou até em um aumento da expressão de genes normalmente ativos. Da mesma forma, o aumento da atividade das HDACs e diminuição da atividade das HATs, podem provocar redução na expressão e silenciamento de diversos genes de maneira nãoespecífica. Por outro lado, pode haver um aumento do recrutamento das HATs e HDACs juntamente com complexos co-ativadores e co-repressores, para regiões promotoras de genes específicos que desempenham papéis importantes na regulação do ciclo celular (MAHLKNECH; OTTMANN; HOELZER, 2000).

Assim, os efeitos da desregulação no mecanismo de acetilação podem gerar um descontrole epigenético na atividade transcricional de vários genes ou de genes específicos desencadeando eventos que contribuem para a transformação maligna.

De qualquer forma, a repressão transcricional de genes supressores tumorais resultante da superexpressão e recrutamento anormal das HDACs para regiões promotoras de genes supressores de tumor é considerado um evento comum no câncer. Além disso, o papel das HDACs no desenvolvimento do câncer, não se restringe somente a desacetilação de proteínas histonas. Sabe-se que as HDACs também atuam sobre a desacetilação de proteínas não histonas importantes envolvidas na progressão do ciclo celular (ROPERO; ESTELLER, 2007). A 
Tabela 8 mostra uma lista de genes importantes no desenvolvimento do câncer e cuja expressão é alterada na presença de iHDACs.

Tabela 8 - Genes envolvidos no desenvolvimento e progressão do câncer cuja expressão é alterada na presença de iHDACs.

\section{FUNÇÃO \\ GENES}

Ciclo Celular Ciclina-A, Ciclina-E, Ciclina-B1, Ciclina-D1 e D3, p21, p53,

Apoptose

CD95/CD95, gelsolin, Bax, Bcl-2

Fatores de

GATA-2, c-Myc, RAR $\alpha$ e RAR $\beta$

Transcrição

Outros

ErbB1, erbB2, Raf-1, MMP-2, tob-1, p55 Cdc, PKCd, HM89, HSP70, ICAM-1, STRA13, hTERT, IL-6 receptor, IL-2, -8 and -10 , VEGF, Notch, CPA3

(RUIJTER et al., 2003).

Todas estas observações sugerem um papel fisiológico importante das HDACs na manutenção da proliferação, sobrevivência e inibição da diferenciação celular. Além de ser um alvo terapêutico importante, a atividade geral ou individual das HDACs pode estar associada a fatores prognósticos.

Apesar de várias evidências indicando um papel importante destas enzimas no desenvolvimento do câncer, não foram observados na literatura, trabalhos relativos à expressão das HDACs relacionada as características clínicas e do prognóstico de pacientes portadores de LLA. 
Neste estudo foi observada uma expressão aumentada do gene $H D A C 1$ no grupo de pacientes com LLA que apresentaram uma resposta melhor ao tratamento (Teste de Mann-Whitney; $\mathrm{p}=0,036$ ). O número total de pacientes analisados quanto à resposta ao tratamento foi de 36 , sendo que 29 pertenciam ao grupo dos bons respondedores e 7 ao grupo dos maus respondedores. Nesta mesma análise, o teste de Fisher revelou resultados semelhantes, mas que não foram estatisticamente significativos $(\mathrm{p}=0,061)$. De qualquer forma, o resultado obtido através da aplicação do teste de Fisher, mostrou um valor próximo do nível de significância adotado neste estudo.

Em um estudo realizado por Zhang et al. (2005), demonstrou uma relação importante entre a expressão aumentada do gene $H D A C 1$ em pacientes com carcinoma de mama invasivo e melhores resultados relativos a fatores clinico patológicos, entretanto, os motivos dessa relação não são claros. Por outro lado, Sasaki et al. (2004), mostraram um aumento da expressão do gene $H D A C l$ em estágios mais avançados de câncer de pulmão. Além disso, outro estudo realizado por Rikimaru et al. (2007), sugeriu que a expressão elevada da HDAC1 pode desempenhar um papel importante na agressividade de carcinomas hepatocelulares além de representar um biomarcador importante no prognóstico dos pacientes.

Como pode ser observado nos exemplos citados, o aumento da expressão do gene $H D A C 1$ pode estar correlacionado tanto com resultados favoráveis como 
desfavoráveis em relação ao prognóstico dos pacientes dependendo do tipo de neoplasia analisada. Assim, é possível que o aumento da expressão do gene $H D A C 1$ em amostras de medula óssea de pacientes portadores de LLA possa ser um indicador de pacientes de prognóstico favorável em relação à resposta ao tratamento. No entanto, esses resultados devem ser analisados com cautela devido ao pequeno número de amostras.

Outro resultado importante observado neste estudo foi à expressão aumentada do gene $H D A C 2$ no grupo de pacientes do gênero masculino (Teste de Fisher $p=0,038)$. Neste caso, o número total de pacientes analisados foi de 46 , sendo que 23 foram do sexo masculino e 23 do sexo feminino. O teste de MannWhitney revelou resultados semelhantes, mas que não foram estatisticamente significativos $(p=0,052)$. Apesar desses resultados encontrados, não se sabe muito a respeito da base molecular envolvida nas diferenças em relação ao prognóstico dos pacientes do gênero masculino e feminino.

O gene $H D A C 2$ também mostrou uma expressão relativa aumentada nos pacientes de alto risco com valor de "p" próximo do nível de significância adotado (Teste de Fisher $\mathrm{p}=0,060$ e Teste de Mann-Whitney $\mathrm{p}=0,062$ ). Também foi observada uma expressão aumentada do gene $H D A C 2$ com nível de significância próximo de 0,05 , em pacientes com uma sobrevida menor através da comparação das curvas de Kaplan-Meier realizadas pelo teste de Log-Rank com valor de p = 
0,065. Acredita-se que estes resultados poderiam apresentar valor estatístico se o número de amostras analisadas fosse maior. Assim, poderíamos sugerir uma possível relação entre o aumento da expressão do gene $H D A C 2$ observada nas amostras de medula óssea de pacientes portadores de LLA pertencentes ao grupo de alto risco e com sobrevida menor.

Um estudo realizado por Weichert et al. (2008a) referente à expressão das HDACs de Classe I (HDAC1, 2 e 3) em câncer de próstata, mostrou um aumento da expressão das HDACs 1, 2 e 3 em tecido neoplásico comparando se com tecido normal e surpreendentemente a expressão aumentada da HDAC2 também foi correlacionada com uma sobrevida menor dos pacientes. Além disso, a expressão aumentada da HDAC2 tem sido relacionada a estágios patológicos mais avançados em tumores gástricos (WEICHERT et al., 2008b).

Apesar da elucidação das diferentes funções que determinadas HDACs desempenham em diferentes tecidos, esses dados sugerem que o aumento expressão da HDAC2 pode representar um fator prognóstico desfavorável comum em alguns tipos de neoplasias.

Até o momento, não há dados conclusivos em relação ao padrão geral de expressão das HDACs no câncer, entretanto vários estudos tem mostrado expressão alterada de membros individuais das HDACs. 
A expressão aumentada da HDAC2 tem sido observada em tumores cervicais (HUANG et al., 2005), gástricos (SONG et al., 2005) e em carcinoma coloretal (ZHU et al., 2004). Além disso, em alguns tipos específicos de câncer mutações truncadas no gene $H D A C 2$ podem conferir resistência ao tratamento com iHDAC (ROPERO et al., 2006). Além de apresentar potencial como indicador do prognóstico em algumas neoplasias, esses dados sugerem um papel importante da HDAC2 no processo de carcinogênese.

No presente estudo também foi realizada uma comparação entre os valores da expressão relativa dos genes de classe I das HDACs em 46 amostras de medula óssea de pacientes portadores de LLA e 10 amostras de doadores sem doença hematológica. $\mathrm{O}$ gene $H D A C 1$ não mostrou grandes diferenças em relação à expressão nas amostras de medula óssea de pacientes portadores de LLA e nas amostras de doadores sem doença hematológica. Por outro lado, os genes $H D A C s$ 2, 3 e 8 mostraram uma expressão significativamente maior nas amostras de pacientes com LLA. Assim como foi demonstrado em alguns estudos relativos a carcinomas de próstata e câncer gástrico (WEICHERT et al., 2008a; WEICHERT et al., 2008b), é possível que a atividade aumentada de determinadas HDACs esteja associada a estágios menos avançados de diferenciação e com a proliferação de células neoplásicas na LLA. Apesar dessas observações é importante ressaltar que a 
medula óssea de um doador sem doença hematológica pode não representar a contraparte normal da medula óssea de um paciente com LLA (REGO et al., 2001). Os genes HDAC3 e HDAC8 mostraram uma expressão significativamente maior nas amostras de medula óssea dos pacientes portadores de LLA quando comparadas com as amostras de medula óssea de doadores sem doença hematológica, entretanto os valores da expressão não tiveram relação com as características clínicas e prognóstico analisadas. Por outro lado, o gene $H D A C l$ não mostrou diferenças significativas em relação à expressão nas amostras dos pacientes portadores de LLA e as amostras de doadores sem doença hematológica, mas revelou diferenças na expressão em relação à resposta ao tratamento dos pacientes portadores de LLA.

É importante considerar que o controle da atividade das HDACs depende também do recrutamento de co-repressores, das interações com outras proteínas e outras modificações pós traducionais (GALLINARI et al., 2007). Além disso, a hiperacetilação das histonas nem sempre resulta diretamente da perda de função das HDACs, mas pode resultar de alterações em seqüências de DNA alvo específicas das HDACs (ROPERO; ESTELLER, 2007). Assim, as alterações nesses componentes que formam complexos juntamente com as HDACs, também podem alterar o processo de repressão transcricional. 
De qualquer forma, a compreensão dos mecanismos epigenéticos envolvidos nos sistemas de programação gênica, pode contribuir de forma significativa para o desenvolvimento de novas estratégias referentes ao tratamento e controle do câncer. Apesar dos avanços obtidos no tratamento, a LLA continua sendo uma causa de morte importante, principalmente entre as crianças e adolescentes e a identificação de novos marcadores moleculares que possam ser considerados fatores prognósticos, podem não somente aumentar o índice de cura, mas melhorar a qualidade de vida dos pacientes. 
7. CONCLUSÕES 


\section{CONCUSÕES}

O gene $H D A C 1$ mostrou uma expressão aumentada nas amostras de pacientes ao tratamento (Teste de Mann-Whitney).

$\mathrm{O}$ gene $H D A C 2$ foi mais expresso em pacientes do gênero masculino (Teste de Fisher).

O grupo de pacientes portadores de LLA mostrou uma expressão aumentada dos genes $H D A C 2, H D A C 3$ e $H D A C 8$, em relação aos doadores de medula óssea sem doença hematológica.

Foi observada correlação linear entre a expressão dos genes de classe I das HDACs, exceto entre $H D A C 1$ e $H D A C 8$.

Esses resultados sugerem que a expressão dos genes de classe I das HDACs apresentam correlações com as características biológicas dos pacientes portadores de LLA, necessitando de novos estudos com um número maior de amostras e realização de testes funcionais. 
8. REFERÊNCIAS BIBLIOGRÁFICAS 


\section{REFERÊNCIAS BIBLIOGRÁFICAS}

Acharya MR, Sparreboom A, Venitz J, Figg W D. Rational development of histone desacetilases inhibitors as anti-cancer agents: a review. Molecular Pharmacology. 2005; 68: 917-932.

Adcock IM, Ford P, Ito K, Barnes, PJ. Epigenetics and Airways Disease. BioMed Central. 2006; 7: 1-19.

Alfrey VG, Faulkner R, Mirsky AE. Acetylation and methylation of histones and their possible role in the regulation of RNA synthesis. Proceedings of the National Academy of Sciences. 1964; 51: 786-94.

Beillard E, Pallisgaard N, van der Velden VH, Bi W, Dee R, van der Schoot E, Delabesse E, Macintyre E, Gottardi E, Saglio G, Watzinger F, Lion T, van Dongen JJ, Hokland P, Gabert J. Evaluation of candidate control genes for diagnosis and residual disease detection in leukemic patients using 'real-time' quantitative reverse-transcriptase polymerase chain reaction (RQ-PCR) - a Europe against cancer program. Leukemia. 2003; 17(12): 2474-2486.

Baylin SB, Ohm JE. Epigenetic gene silencing in cancer - a mechanism for early oncogenic pathway addiction? Nature Reviews Cancer. 2006; 6: 107-116. 
Belson M, Kingsley B, Holmes A. Risk Factors for Acute Leukemia: A Review. Environmental Health Prospectives. 2007; 115(1): 138-145.

Bene MC, Faure GC. CD10 in Acute Leukemias. Haematologica. 1997; 82: 205210.

Bernhard D, Skvortsov S, Tinhofer I, Hubl H, Greil1 R, Csordas A, Kofer R. Inhibition of histone deacetylase activity enhances Fas receptor-mediated apoptosis in leukemic lymphoblasts. Cell Death and Differentiation. 2001; 8: 1014-1021.

Bernstein BE, Meissner A, Lander ES. The Mammalian Epigenome. Cell. 2007; 128: 669-681.

Beutler E. The treatment of acute leukemia: past, present, and future. Leukemia. 2001; 15(4): 658-661.

Bi G, Jiang G. The Molecular Mechanism of HDAC Inhibitors in Anticancer Effects. Cellular \& Molecular Immunology. 2006; 3 (4): 285-290.

Canalle R, Burim RV, Tone LG, Takahashi CS. Genetic Polimorphisms and susceptibility to childhood acute lymphoblastic leukemia. Environmental and Molecular Mutagenesis. 2004; 43: 100-109.

Carroll WL, Bhojwani D, Min DJ, Raetz E, Relling M, Davies S, Downing JR, Willman CL, Reed JC. Pediatric acute lymphoblastic leukemia. Hematology. 2003: 103-131. 
Chen H, Tini M, Evans RM. HATs on and beyond chromatin. Current Opinion in Cell Biology 2001, 13:218-224

Cress WD, Seto E. Histone Deacetylases, Transcriptional. Control, and Cancer. Journal of Cellular Physiology. 2000; 184: 1-16.

Curtin M, Glaser K. Histone deacetylase inhibitors: the Abbott experience. Current Medicinal Chemistry. 2003; 10: 2373-2392.

Downing JR, Shannon KM. Acute leukemia: a pediatric perspective. Cancer Cell. 2002; $2: 437-445$.

Driever PH, KnuÈpfer MM, Cinat J, Wolff JE. Valproic acid for the treatment of pediatric malignant glioma. Klinische. Padiatrie. 1999; 211: 323-328.

Drummond, DC, Noble, CH, Kirpotin, DB, Guo, Z, Scott, GK, Benz CC. Clinical Development Of Histone Deacetylase Inhibitors As Anticancer Agents. Annual Review of Pharmacology and Toxicology. 2005; 45: 495-528.

Ducasse M, Brown MA. Epigenetic Aberrations and Cancer. Molecular Cancer. 2006; 5(60): 1-10.

Esteller M, Almouzni G. How epigenetics integrates nuclear functions. European Molecular Biology Organization (EMBO) reports. 2005; 6: 624-628.

Esteller M. Epigenetics provides a new generation of oncogenes and tumoursuppressor genes. British Journal of Cancer. 2006; 94: 179-183. 
Evans WE, MacLeod HL. Pharmacogenomics - Drug disposition, drug targets and side effects. New England Journal of Medicine. 2003; 348: 538-549.

Evans WE, Relling MV. Moving towards individualized medicine with pharmacogenomics. Nature. 2004; 429: 464-468.

Farias MG, Castro SM. Diagnóstico laboratorial das leucemias linfóides agudas. Jornal Brasileiro de Patologia e Medicina Laboratorial. 2004; 40(4): 91-98.

Fenrick R, Hiebert SW. Role of Histone Deacetylases in Acute Leukemia. Journal of Cellular Biochemistry Supplements. 1998; 72(30): 194-202.

Feinberg AP, Tycko B. The history of cancer epigenetics. Nature Reviews Cancer. 2004; 4: 143-153.

Fumaro VMBO, et al. Diretrizes para apresentação de dissertações e teses da USP: Documento Eletrônico Impresso. Sistema Integrado de Bibliotecas da Universidade de São Paulo (SIBi-USP). 2004: 110p.

Galm O, Herman JG, Baylin SB. The Fundamental Role of Epigenetics in Hematopoietic Malignancies. Blood Reviews. 2006; 20: 1-13.

Gallinari P, Di Marco S, Jones P, Pallaoro M, Steinkühler C. HDACs, histone deacetylation and gene transcription: from molecular biology to cancer therapeutics. Cell Research. 2007; 17: 195-211. 
Gaynon PS. Childhoood Acute Lymphoblastic Leukemia and Relapse. US Special Populations Pediatrics Review. 2006: 44-48.

Gaynon PS, Trigg ME, Heerema NA, Sensel MG, Sather HN, Hammond GD, Bleyer WA. Children's Cancer Group trials in childhood acute lymphoblastic. leukemia: 1983-1995. Leukemia. 2000; 14: 2223-2233.

Glaser K B, Staver MJ, Waring JF, Stender J, Ulrich RG, Davidsen SK. Gene expression profiling of multiple histone deacetylase (HDAC) inhibitors: defining a common gene set produced by HDAC inhibition in T24 and MDA carcinoma cell lines. Mol. Cancer Ther. 2003; 2: 151-163.

Goldman J. Chronic Myeloid Leukemia-Past, Present and Future. Seminars in Hematology. 2003; 40(1): 1-3.

Grupo Brasileiro de Tratamento da Leucemia Infantil. GBTLI LLA-93. Protocolo de Tratamento da Leucemia Linfóide Aguda em Crianças. Campinas [s.n.]; 1993.

Grupo Brasileiro de Tratamento da Leucemia Infantil. GBTLI LLA-99. Protocolo de Tratamento da Leucemia Linfóide Aguda em Crianças. Campinas [s.n.]; 1999.

Gunz FW. Leukemia in the past. In: Henderson ES, Lister TA (eds). Leukemia. WB Saunders Company: Philadelphia. 1990: 3-11.

Gui CY, Ngo L, Xu WS, Richon VM, Marks PA. Histone deacetylase (HDAC) inhibitor activation of $\mathrm{p} 21 \mathrm{WAF} 1$ involves changes in promoter-associated proteins, including HDAC1. Proc. Natl. Acad. Sci. USA. 2004; 101: 1241-1246. 
Harrison CJ. Acute lymphoblastic leukaemia. Best Practice \& Research Clinical Haematology. 2001; 14(3): 593-607.

Hildmann C, Riester D, Schwienhorst A. Histone deacetylases - an important class of cellular regulators with a variety of functions. Applied Microbiology \& Biotechnology. 2007; 253 (7): 1-11.

Holliday R. Epigenetics: A Historical Overview. Epigenetics. 2006; 1 (2): 76-80.

Huang BH, Laban M, Leung CH, Lee L, Lee CK, Salto-Tellez M, Raju GC, Hooi SC. Inhibition of histone deacetylase 2 increases apoptosis and p21Cip1/WAF1 expression, independent of histone deacetylase 1. Cell Death \& Differenciation. 2005; 12: 395-404.

Infante-Rivard C, Guiguet M. Family History of hematopoietic and others cancers in childrem with acute lymphoblastic leukemia. Cancer Detection \& Prevention. 2004; 28: 83-87.

Irons RD, Stillman WS. The Process of Leukemogenesis. Environmental Health Perspectives. 1996; 104(6): 1239-1246.

Jones PA, Baylin SB. The Fundamental Role of Epigenetics Events in Cancer. Nature Reviews Genetic. 2002; 3: 415-428.

Kebriaei P. Acute Lymphoblastic Leukemia: Diagnosis and Classification. Best Pratice \& Research Clinical Haematology. 2003; 15(4): 597-621. 
Kimmins S, Sassone-Corsi P. Chromatin remodelling and epigenetic features of germ cells. Nature. 2005; 434: 583-589.

Knudson AG. Mutation and cancer: statistical study of retinoblastoma. Proccedings Proceedings of the National Academy of Sciences of the United States of America. 1971; 68(4): 820-823.

Kurdistani SK. Histone modifications as markers of cancer prognosis: a cellular view. British Journal of Cancer. 2007; 97: 1-5.

Larson RA. Acute Lymphoblastic Leukemia: Older Patients and Newer Drugs. Hematology. 2005: 131-136.

Laird PW. Cancer Epigenetics. Human Molecular Genetics. 2005; 14(1): 65-76.

Lehmann U, Brakensiek K, Kreipe H. Role of epigenetic changes in hematological malignancies. Annals of Hematology. 2004; 83: 137-152.

Livac KJ, Schmittgen TD. Analysis of relative gene expression data using real time quantitative PCR and the $2^{-\Delta \Delta C t}$ method. Methods. 2001; 25: 402-408.

Lu Q, Qiu X, Hu N, Wen H, Su Y, Richardson BC. Epigenetics, disease, and therapeutic interventions. Ageing Research Reviews. 2006; 5: 449-467.

Lund AH, van Lohuizen M. Epigenetics and cancer. Genes \& Development. 2004; 18: 2315-2335. 
Mahlknecht U, Ottmann OG, Hoelzer D. When the Band Begins to Play: Histone Acetylation Caught in the Cross of Gene Control. Molecular Carcinogenesis. 2000; 27: $268-271$.

Margolin JF, Steuber CP, Poplack DG. Acute Lymphoblastic Leukemia. IN Pizzo PA, Poplack DG. Principles and Pratice of Pediatric Oncology. Philadelphia: Lippincott-Haven, Cap. 19, p. 489-544, 2002.

Marks PA, Richon VM, Rifkind RA. Histone deacetylase inhibitors: inducers of differentiation or apoptosis of transformed cells. Journal of the National Cancer Institute. 2000; 92(15): 1210-1215.

Marks PA, Rifkind RA, Richon VM, Breslow R. Inhibitors of Histone Deacetylase are Potentially Effective Anticancer Agents. Clinical Cancer Research. 2001; 7: 759-760.

Marks PA, Millery T, Richony VM. Histone deacetylases. Current Opinion in Pharmacology. 2003; 3: 344-351.

Marks PA. Discovery and development of SAHA as an anticancer agent. Oncogene. 2007; 26: 1351-1356.

Minucci S, Pelicci PG. Histone Deacetylase Inhibitors and the Promise of Epigenetic (and more) Treatments for Cancer. Nature Reviews Cancer. 2006; 6: 3851. 
Minucci S, Nervi C, Coco FL, Pelicci PG. Histone deacetylases: a common molecular target for differentiation treatment of acute myeloid leukemias? Oncogene. 2001; 20: 3110-3115.

Moppett J, Burke GAA, Steward CG, Oakhill A, Goulden NJ. The clinical relevance of detection of minimal residual disease in childhood acute lymphoblastic leukaemia. Journal of Clinical Pathology. 2003; 56: 249-253.

Miyamoto K, Ushijima T. Diagnostic and Therapeutic Applications of Epigenetics. Japanese Journal of Clinical Oncology. 2005; 35(6): 293-301.

Park JH, Jung Y, Kim TY, Kim SG, Jong HS, Lee JW, Kim DK, Lee JS, Kim NK, Kim TY, Bang YJ. Class I Histone Deacetylase-Selective Novel Synthetic Inhibitors Potently Inhibit Human Tumor Proliferation. Clinical Cancer Research 2004; 10: 5271-5281.

Peart MJ, Tainton KM, Ruefli AA, Dear AE, Sedelies KA, O'Reilly LA, Waterhouse NJ, Trapani JA, Johnstone RW. Novel Mechanisms of Apoptosis Induced by Histone Deacetylase Inhibitors. Cancer Research. 2003; 63: 4460-4471.

Pui, C.H. Diagnosis And Classification. In: Pui, C.H. Childhood Leukemia. Cambridge: Cambridge University Press, 1999a. Cap 2, P. 19-37.

Pui CH, Boyett JM, Relling MV, Harryson PL, Rivera GK, Behm FG, Sandlund JT, Ribeiro RC, Rubnitz JE, Gajjar A, Evans WE. Sex Differences in Prognosis for Children with Acute Lymphoblastic Leukemia. Journal of Clinical Oncology. 1999b; 17(3): 818-824. 
Pui CH. Recent advances in childhood acute lymphoblastic leukemia. The New England Journal of Medicine. 2004; 103(2): 85-95.

Pui CH, Evans WE. Treatment of acute lymphoblastic leukemia. The New England Journal of Medicine. 2006; 354(2): 166-178.

Pui $\mathrm{CH}$, Jeha S. New therapeutic strategies for the treatment of acute lymphoblastic leukaemia. Nature Reviews. 2007; 6: 149-165.

Reichmann R. Acute Lymphoblastic Leukaemia: A Review. Trinity Student Medical Journal. 2000; 1: 26-28.

Rego EM, Garcia AB, Carneiro JJ, Falcão RP. Immunophenotype of normal and leukemic bone marrow B-precursors in a Brazilian population. A comparative analysis by quantitative fluorescence cytometry. Brazilian Journal of Medical and Biological Research. 2001; 34: 183-194.

Ries LAG, Kosary CL, Hankey BF, Miller BA, Clegg L, Mariotto A, et al. SEER Cancer Statistics Review 1973-1995. NHI Publ no 98-2789. Bethesda, MD: National Cancer Institute. 1998.

Rikimaru T, Taketomi A, Yamashita Y, Shirabe K, Hamatsu T, Shimada M, Maehara Y. Clinical Significance of Histone Deacetylase 1 Expression in Patients with Hepatocellular Carcinoma. Oncology. 2007; 72: 69-74.

Romanski A, Bacic B, Bug G, Pfeifer H, Gul H, Remiszewski S, Hoelzer D, Atadja P, Ruthardt, M. Ottmann OG. Use of a novel histone deacetylase inhibitor to induce 
apoptosis in cell lines of acute lymphoblastic leukemia. Haematologica. 2004; 89: 419-426.

Ropero S, Fraga MF, Ballestar E, Hamelin R, Yamamoto H, Boix-Chornet M, Caballero R, Alaminos M, Setien F, Paz MF, Herranz M, Palácios J, Arango D, Orntoft TF, Aaltonen LA, Schwartz Jr S, Esteller M. A truncating mutation of HDAC2 in human cancers confers resistance to histone deacetylase inhibition. Nature Genetics. 2006; 38(5): 566-569.

Ropero S, Esteller M. The role of histone deacetylases (HDACs) in human cancer. Molecular Oncology. 2007; 1: 19-25.

Roth SY, Denu JM, Allis CD. Histone Acetyltransferases. Annual Review of Biochemistry. 2001; 70: 81-120.

Rubnitz JE, Pui CH. Childhood Acute Lymphoblastic Leukemia. The Oncologist 1997; 2: 374-380.

Rubnitz JE, Pui CH. Recent advances in the treatment and understanding of childhood acute lymphoblastic leukaemia. Cancer Treatment Reviews. 2003; 29: 31-44.

Ruijter AJM, Gennip AH, Caron HN, Kemp S, Van Kuilenburg, ABP. Histone deacetylases (HDACs): characterization of the classical HDAC family. Biochemical Journal. 2003; 370: 737-749. 
Sasaki H, Moriyama S, Nakashima Y, Kobayashi Y, Kiriyama M, Fukai I, Yamakawa Y, Fujii Y. Histone deacetylase 1 mRNA expression in lung cancer. Lung Cancer. 2004; 46(2): 171-178.

Seligson DB, Horvath S, Shi T, Yu H, Tze S, Grunstein M, Kurdistani SK. Global histone modification patterns predict risk of prostate cancer recurrence. Nature. 2005; 435: 1262-1266.

Senese.S, Zaragoza K, Minardi S,Muradore I, Ronzoni S, Passafaro A, Bernard L, Draetta GF, Alcalay M, Seiser C, Chioccal S. Role for Histone Deacetylase 1 in Human Tumor Cell Proliferation. Molecular and Cellular Biology. 2007; 27(13): 4784-4795.

Song J., Noh JH, Lee JH, Eun JW, Ahn YM, Kim SY, Lee SH, Park WS, Yoo NJ, Lee JY, Nam SW. Increased expression of histone deacetylase 2 is found in human gastric cancer. Acta Pathologica, Microbiologica et Immunologica Scandinavica. 2005; 113: 264-268.

Scrideli CA, Kashima S, Cipolloti R, Defavery R, Bernardes JE, Tone LG. Minimal residual disease in Brazilian children with acute lymphoid leukemia: comparison of three detection methods by PCR Leukemia Research. 2002; 26: 431438.

Scrideli CA, Queiroz RG, Bernardes JE, Valera ET, Tone LG. PCR Detection of clonal IgM and TCR gene rearrangments at the end of induction as a non-remission criterion in children with ALL: comparison with Standard morphologic analysis and risk group classification. Medical and Pediatric Oncology. 2003; 41(1): 10-16. 
Smith M, Arthur D, Camitta B, Carroll AJ, Crist W, Gaynon P, Gelber R, Heerema N, Korn EL, Link M, Murphy S, Pui CH, Pullen J, Reamon G, Sallan SE, Sather H, Shuster J, Simon R, Trigg M, Tubergen D, Uckun F, Ungerleider R. Uniform approach to risk classification and treatment assignment for children with acute lymphoblastic leukemia. Journal of Clinical Oncology. 1996; 14: 18-24.

Ting AH, McGarvey KM, Baylin SB. The Cancer Epigenome - Components and Funcional Correlates. Genes \& Development. 2006; 20: 3215-3231.

Turner BM. Cellular Memory and Histone Code. Cell. 2002; 111(1), 285-291.

Uckun FM, Sensel MG, Sun L, Steinherz PG, Trigg ME, Heerema NA, Sather HN, Reaman GH, Gaynon PS. Biology and treatment of childhood T-lineage acute lymphoblastic leukemia. Blood. 1998; 91(3): 735-46.

van der Velden VHJ, Hochhaus A, Cazzaniga G, Szczepanski T, Gabert J, van Dongen JJM. Detection of minimal residual disease in hematologic malignancies by real-time quantitative PCR: principles, approaches, and laboratory aspects. Leukemia. 2003; 17: 1013-1034.

Yang Z, Zhang H, Kumar R. Regulation of E-cadherin. Breast Cancer. 2005; 8(3): $1-4$.

Weichert W, Roske A, Gekeler V, Beckers T, Stephan C, Jung K, Fritzsche FR, Niesporek S, Denkert C, Dietel M, Kristiansen G. Histone deacetylases 1, 2 and 3 are highly expressed in prostate cancer and HDAC2 expression is associated with shorter PSA relapse time after radical prostatectomy. British Journal of Cancer. 2008a; 98: 604-610. 
Weichert W, Röske A, Gekeler V, Beckers T, Ebert MPA, Pross M, Manfred D, Denkert C, Röcken C. Association of patterns of class I histone deacetylase expression with patient prognosis in gastric cancer: a retrospective analysis. Lancet Oncology. 2008b; 9: 139-48.

Weinhold B. Epigenetics: The Science of Change. Environmental Health Perspectives. 2006; 114(3): 160-167.

Wilson AJ, Byun DS, Popova N, Murray LB, Italien KL, Sowa Y, Arango D, Velcich A, Augenlicht LH, Mariadason JM. Histone deacetylase 3 (HDAC3) and other class I HDACs regulate colon cell maturation and p21 expression and are deregulated in human colon cancer. Journal of Biological Chemistry. 2006. 281:124.

Zhang Z, Yamashita H, Toyama T, Sugiura H, Ando Y, Mita K, Hamaguchi M, Hara Y, Kobayashi S, Iwase1 H. Quantitation of HDAC1 mRNA expression in invasive carcinoma of the Breast. Breast Cancer Research and Treatment. 2005; 94: $11-16$

Zhu P, Martin E, Mengwasser J, Schlag P, Janssen KP, Gottlicher M. 2004. Induction of HDAC2 expression upon loss of APC in colorectal tumorigenesis. Cancer Cell. 2004; 5: 455-463. 


\section{ANEXOS}




\subsection{ANEXO 1}

TERMO DE CONSENTIMENTO LIVRE E ESCLARECIDO

TÍTULO DO TRABALHO: ESTUDO DA EXPRESSÃO DOS GENES DE CLASSE I DAS HISTONAS DESACETILASES (HDAC 1, 2, 3 e 8) EM LEUCEMIA LINFÓIDE AGUDA DE CRIANÇAS E ADOLESCENTES.

Pesquisadores Responsáveis:

Daniel Antunes Moreno, (16) 36022651

Dr. Luíz Gonzaga Tone, (16) 36022772

A Leucemia Linfóide Aguda é o tipo de câncer mais comum em crianças e apresenta grandes chances de cura. É uma doença grave se não for tratada e algumas crianças mesmo submetidas ao tratamento podem apresentar recidiva (volta) da doença. O Objetivo deste trabalho é investigar alterações nas informações genéticas e associação com o prognóstico para a busca de melhores tratamentos e para melhorar as chances de cura das crianças com Leucemia.

O seu filho(a) não será submetido a nenhum procedimento (coleta de sangue, cirurgias, biópsias, raio-X, etc) para a elaboração deste projeto, não trazendo nenhum risco ou sofrimento adicional.

As amostras de estudo fazem parte do Banco de Medula Óssea do Serviço de Oncologia Pediátrica do Hospital das Clínicas da Faculdade de Medicina de Ribeirão Preto da Universidade de São Paulo, conforme Termo de Consentimento 
de Guarda de material assinado. Durante a realização desta pesquisa não haverá nenhum custo para os familiares das crianças que estejam participando da mesma.

À criança e aos seus responsáveis serão garantidos ainda o que segue:

1. O esclarecimento de qualquer dúvida a respeito dos procedimentos, riscos, benefícios e outras situações relacionadas com a pesquisa.

2. A liberdade de retirar o consentimento e deixar de participar do estudo a qualquer momento, sem que isto traga prejuízo à continuidade do tratamento da criança.

3. A segurança de que a criança não será identificada e que será mantido o caráter confidencial de todas as informações obtidas com a criança, com os seus familiares ou no prontuário médico.

4. O compromisso de que quando solicitado, serão prestadas aos responsáveis pela criança, informações atualizadas durante o estudo.

5. O compromisso de que a criança será devidamente acompanhada e assistida durante todo o período de participação do projeto, bem como a de que será garantida a continuidade de seu tratamento após a conclusão dos trabalhos de pesquisa.

6. O ressarcimento de eventuais despesas decorrentes da participação da criança na pesquisa, assim como a indenização, a título de cobertura material, da reparação de danos imediatos ou tardios decorrentes da participação da criança na pesquisa que será realizada na Faculdade de Medicina de Ribeirão Preto da Universidade de São Paulo (FMRP-USP) 
$\mathrm{Eu}$ fui

devidamente esclarecido(a) sobre todas as questões que constam no documento, especialmente no que diz respeito aos objetivos da pesquisa, aos procedimentos que serão realizados, aos riscos e benefícios, a forma de ressarcimento no caso de eventuais despesas, bem como a forma de indenização por danos decorrentes da pesquisa, declaro que tenho pleno conhecimento dos direitos e das condições que foram assegurados e que concordo inteiramente e de livre vontade que meu filho(a) pesquisa.

Ribeirão Preto ___ de___ de____ participe desta Assinatura do Responsável pelo Paciente 


\subsection{ANEXO 2}

\section{CÓPIA DA CARTA DE APROVAÇÃO DO COMITÊ DE ÉTICA}

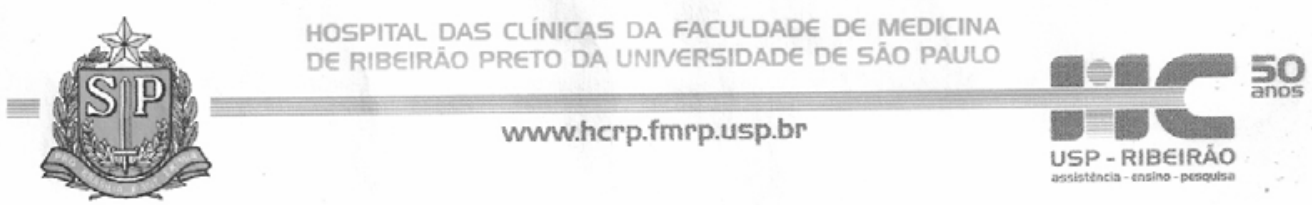

Ribeirão Preto, 06 de dezembro de 2006

Oficio $n^{\circ} 3493 / 2006$

$\mathrm{CEP} / \mathrm{SPC}$

Prezado Senhor,

O trabalho intitulado "ESTUDO DA EXPRESSÃO GÊNICA DA FAMILIA I DAS HISTONAS DEACETILASES (HDAC 1,2,3 E 8) EM LEUCEMIA LINFÓIDE AGUDA DE CRIANÇAS E ADOLESCENTES", foi analisado pelo Comitê de Ética em Pesquisa, em sua $238^{a}$ Reunião Ordinária realizada em 04/12/2006, e enquadrado na categoria: APROVADO, bem como o Termo de Consentimento Livre e Esclarecido, de acordo com o Processo HCRP n ${ }^{\circ} 11750 / 2006$.

Atenciosamente.

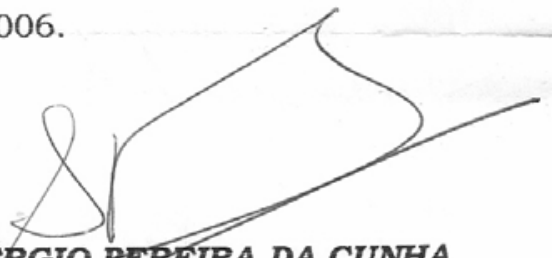

PROF. DR. SÉRGIO PGREIRA DA CUNHA

Coordenador do Comitê de Ética em Pesquise do HCRP e da FMRP-USP

Ilustríssimo Senhor

DANIEL ANTUNES MORENO

PROF. DR. LUIZ GONZAGA TONE (Orientador)

Depto. de Genética - FMRP-USP

Comitê de Ética em Pesquisa HC e FMRP-USP - Campus Universitário FWA - 00002733 ; IRB - 00002186

Fone (16) 3602-2228 - E-mail : cep@hcrp.fmrp.usp.br

Monte Aleare 14048-900 Ribeirão Preto SP 


\section{ANEXO 3}

\section{PROTOCOLOS UTILIZADOS NO LABORATÓRIO DE ONCOLOGIA PEDIÁTRICA DO HC/FMRP-USP}

\section{PBS}

- Dissolver $8 \mathrm{~g}$ de $\mathrm{NaCl}, 0,2 \mathrm{~g}$ de $\mathrm{KCl}, 1,44 \mathrm{~g}$ de $\mathrm{Na}_{2} \mathrm{HPO}_{4}$ em $800 \mathrm{~mL}$ de água destilada.

- Ajustar o pH para 7,4 com $\mathrm{HCl}$;

- Acrescentar água q.s.p. 1 litro;

- Aliquotar a solução e esterilizar em autoclave por 2 minutos;

- Armazenar em geladeira.

\section{2. Água tratada com DEPC}

- Acrescentar DEPC ao volume de água desejado com concentração final de $0,1 \%$.

- Deixar em solução overnight e autoclavar por 20 minutos 